\title{
4. A különleges jogrend magyar szabályozásának történeti fejlődése (a kezdetektől 2011-ig)
}

\author{
DOMANICZKY ENDRE
}

\section{A magyar szabályozás a kezdetektől 1945-ig}

\subsection{Korai szabályozás a magyar és az európai jogrendszerekben}

\subsubsection{A kivételes hatalom és a különleges jogrend fogalmi keretei}

A kivételes hatalom és a különleges jogrend nem új keletû́ intézmények a magyar közjogban. A kivételes hatalom nem más, mint a végrehajtó hatalom számára az alkotmányos rend felfüggesztése révén biztosított túlhatalom. A különleges jogrend pedig a kivételes hatalom időszakában fennálló jogrend, amelynél a különleges szó az állami múködés megszokott rendjétől való eltérésre utal. ${ }^{1}$

A kivételes hatalom fogalmának lényegi elemei: az alkotmányos rend, a felfüggesztés és a túlhatalom. Az alkotmányos rend egy stabil, többszereplős államszervezetet feltételez,

I A különleges szó akár a különös szinonimájaként is felfogható, hiszen az általánostól eltérő, speciális jogi rezsimre alkalmazzák.

Dr. Domaniczky Endre, PhD

endre.domaniczky@mfi.gov.hu

vezető kutató (Mádl Ferenc Összehasonlító Jogi Intézet)

Domaniczky, E. (2021) ‘A különleges jogrend magyar szabályozásának történeti fejlődése (a kezdetektől 2011-ig)' in Nagy, Z., Horváth, A. (szerk.) A különleges jogrend és nemzeti szabályozási modelljei, 78-121. o. Budapest: Mádl Ferenc Összehasonlító Jogi Intézet.

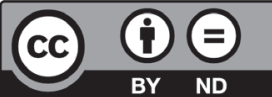


ez az európai államoknál általában az újkorban alakult ki. Alkotmányos rend alatt gyakran az írott alkotmány meglétére gondolunk, ám ezek csak a 18. század végétől kezdenek elterjedni. Alkotmányos rend azonban írott alkotmány hiányában is létezhet, ezt éppen a kivételes hatalommal kapcsolatos korai magyar példák igazolják (1.1.3. pont). A felfüggesztés az alkotmányos rend kikapcsolásának időleges, korlátozott voltára utal. A kivételes hatalom gyakorlása tehát csak bizonyos célok elérése érdekében lehetséges, a végrehajtó hatalmat a többi alkotmányos tényező korlátozásával e célok miatt ruházzák fel - a normál alkotmányos keretek között elfogadott szabályok által - többletjogosítványokkal. A túlhatalom kifejezés a többletjogosítványok tartalmát magyarázza. Normál esetben a végrehajtó hatalom intézkedései más hatalmi ágak által kontrolláltak. A túlhatalom ehhez képest tesz lehetôvé bizonyos intézkedéseket, eljárásokat, amelyeket az elérendő célok kivételessége, rendkívülisége indokol.

Bár a fogalom lényegi elemei között nem szerepelt a kiemelt állami vagy társadalmi cél meghatározása, érdemes erről is néhány szót ejteni. A kivételes hatalom átfogó szabályozásának igénye a polgári államok kiteljesedését követően, a 19. század második felében jelentkezett. A mai jogállamfogalom több eleme, előfeltétele ekkor már létezett a közjogban. ${ }^{2}$ Ezek időleges korlátozásának, kiiktatásának lehetôsége révén nyerte el a kivételes hatalom és a különleges jogrend a mai jelentéstartalmát. E közjogi garanciák felfüggesztésével csak kiemelten fontos állami, társadalmi érdek, afféle állami végszükséghelyzet állitható szembe. ${ }^{3}$ Ilyenek lehetnek a mai szóval a közrend, a nemzetbiztonság, a közegészség és a nemzetgazdaság védelmének esetkörei, amelyek nagyrészt a 20. századi államokat és közösségeket egyaránt fenyegetô eseményekre reflektálva kristályosodtak ki és épültek be - sztenderdként a jogállam fogalmának ismérvei közé (a 20. század második felében). A kivételes hatalom ugyanis egy korlátozott eszköz, ahogy a jogállamban „maga a közhatalom sem korlátlan”. ${ }^{4}$

Összegezve a fogalmi elemeket látható, hogy a kivételes hatalom és a különleges jogrend fogalmak a polgári államok kialakulásával fokozatosan nyerték el mai jelentéstartalmukat. Mindez nem jelenti azt, hogy e jogintézménynek ne lettek volna korábbi jogtörténeti előzményei. Az alábbiakban vázlatosan ezek szabályozását követjük nyomon elsősorban Magyarországon, de kitekintéssel egyes európai államokra is.

\subsubsection{A kivételes hatalom megjelenése az európai országok jogában}

A rendi keretek között kivételes hatalommal elsősorban büntetőjogi vagy katonai szempontból találkozhatunk. ${ }^{5} \mathrm{~A}$ kivételes hatalom szabályozásának egységesülését, a jogállamfo-

2 Így például a hatalommegosztás elve, a polgári szabadságjogok egy része, a parlament szuverenitásának elmélete.

3 Lásd még: Polner, 1916, 86-87. o.

4 Lásd a 11/1992. (III. 5.) AB határozatot (Alkotmányos elvek és esetek, 1996, 538. o.).

5 Lásd bővebben: Mezey, 2015, 25-32. o. 
galommal párhuzamos fejlődését a 18. század végén bekövetkező amerikai és francia forradalom alkotmánytörténeti folyamatai segítették elő.

Az Egyesült Államok alkotmánya (1787) már biztosította - szúk körben - az elnök számára a kivételes hatalom lehetőségét, ${ }^{6}$ egyúttal a későbbi alkotmányozási folyamatoknál a hatalommegosztás tekintetében hivatkozási alappá vált. Az Emberi és Polgári Jogok Nyilatkozata (1789) pedig felsorolta azokat a jogokat, amelyek lassanként egyetemes emberi jogokká válva lehetôvé tették „az egyéni szabadság megalapozását és biztosítékokkal való körülbástyázását"? ${ }^{7}$

Nem véletlen, hogy Franciaországban viszonylag korán, már az 1799-es alkotmányban meghatározták az alkotmány felfüggesztésének esetköreit, ${ }^{8}$ hiszen a hatalmi ágak (együtt) múködését e szabályozás nagymértékben megkönnyítette. Napóleon 1815-ös alkotmánytörvénye ugyancsak foglalkozott a különleges jogrend kérdésével, amikor kimondta, hogy az ostromállapot csak külhatalom támadása, illetve belső zavargások esetén vezethető be. ${ }^{9}$ A 19. század nagy részében azonban a kérdést alkotmányi felhatalmazás alapján törvényi szinten szabályozták. ${ }^{10}$

Németországban a kivételes hatalom egyik korai szabályozása az 1851-es porosz alkotmányban található, amely miután felsorolja az állampolgári jogokat, háború vagy belső zavargások esetére ezek felfüggesztését is lehetővé teszi. ${ }^{11} \mathrm{~A}$ kérdést az alkotmány felhatalmazása alapján 1851-ben külön törvény bontotta ki, amelyet azért kell megemlíteni, mert az 1871-es német birodalmi alkotmány kivételes hatalomról szóló szabályozása e törvényre épült. ${ }^{12}$ Hasonló az 1912-es bajor törvény által alkalmazott megoldás is. ${ }^{13}$

Oroszországban, ahol „egészen a XX. század elejéig a cári hatalom teljességét jogi értelemben semmiféle formális norma vagy intézmény nem korlátozta", ${ }^{14}$ az 1906-os alkotmány megemlítette a háborús helyzetet, illetve a kivételes állapotot, mint a különleges jogrend alá tartozó kategóriákat, és az uralkodó jogkörébe utalta az alkalmazási terület meghatározását. ${ }^{15} \mathrm{Az}$ alkotmány egyúttal rögzítette, hogy a részletszabályokat törvényi szinten kell rendezni, de ez a törvény az I. világháború kitöréséig nem készült el, az alkotmányt pedig 1917

6 Vö.: Art. II., Sec 3, Cl 3. - ez ma is létezik (lásd: Jánosi, 1867, II. 60-61. o.). A kivételes hatalom egyesült államokbeli szabályozásának jellegzetességeire lásd bővebben: Mészáros, 2016.

7 Polner, 1917, 25. o.

8 92. \$. Elérhető: https://en.wikisource.org/wiki/Constitution_of_the_Year_VIII (Letöltve: 2020 . június 10.).

9 Lásd a 66. pontot: www.napoleon-series.org/research/government/legislation/c_additional.html (Letöltve: 2020. június 10.).

10 Vö.: Polner, 1917. A francia szabályozás alkotmánytörténeti fejlődésére lásd még: Ságvári, 2017.

11 Lásd: 36. cikk. Elérhető: https://en.wikisource.org/wiki/Constitution_of_the_Kingdom_of_Prussia (Letöltve: 2020. június 10.).

12 Lásd: 66. cikk. Elérhető: https://en.wikisource.org/wiki/Constitution_of_the_German_Empire (Letöltve: 2020. június 10.). Lásd még: Tóth, 1967.

13 Buza, 1915 és Buza, 1917. A későbbi német szabályozásra lásd még: Szabó, 2017.

14 Sz. Bíró, 2017, 137. o.

15 Lásd: 15. és 83. pont. Elérhető: https://tinyurl.com/h8z4V7x8 (Letöltve: 2020. június 5.). 
végén hatályon kívül helyezték. ${ }^{16}$ Jogtörténeti érdekességként említendő, hogy a szovjet államra a végrehajtó hatalom túlsúlya volt jellemző, függetlenül a különböző alkotmányokban rögzített államberendezkedéstől.

Végezetül itt kell röviden megemlékezni a brit szabályozás jellegzetességeiről is. Nagy-Britannia (1801-től Egyesült Királyság) kivételes jogrend tekintetében az eddig felsorolt országoktól némiképp eltérő utat követett. Maga az alapdokumentum is más, mint a kontinentális országokban. Az angol történeti (íratlan) alkotmány ${ }^{17}$ ugyanis nem egyetlen írott jogszabály, hanem századokon keresztül létrejött, organikus konstrukció, amelynek tartalmát folyamatos jogértelmezés révén határozzák meg. ${ }^{18} \mathrm{~A}$ brit kivételes hatalommal kapcsolatos szabályozás gyökerei a közép- és a kora újkorra nyúlnak vissza ${ }^{19}$ (míg a fenti példáknál általában újkori eredetûek). Fontos különbség az is, hogy a kivételes hatalmat lehetôvé tévő jogszabályok már a 18. század második felében is léteztek, évtizedekkel megelőzve a többi ország hasonló megoldásait. ${ }^{20}$

Magyarország a 19. században az Osztrák Császárság, majd az Osztrák-Magyar Monarchia része volt. A kivételes hatalom korai osztrák szabályozásának jellemzőit ezért a következő pontban, a magyar kodifikációs kísérletekhez kapcsolódva mutatjuk be.

\subsubsection{A kivételes hatalom megjelenése a magyar jogban}

A kivételes hatalomra vonatkozó általános szabályozás csak a 20. század elején készült, ám a törvényhozás egyes konkrét esetekben már jóval korábban lehetővé tette az ügyek kivé-

16 Oroszországban egy 1881-es törvény meghatározta a fokozott védelem és a rendkívüli védelem állapotát, és a kormányzókat feljogosította egyes állampolgári jogok korlátozására. 1892-ben ezen túlmenően megjelent a hadiállapot fogalma is, amely a kormányzók számára a belső rend helyreállítása érdekében bármilyen intézkedést lehetôvé tett. Az 1906-os alkotmányban említett külön törvény hiányában a gyakorlatban az említett 1881-es törvényt alkalmazták. Bővebben lásd: Tóth, 1967, 10-11. o.; Búza, 1915.

17 „Angliában ugyanis az alkotmány nem egy törvénynek vagy egyes fötörvényeknek egyenes teremtménye, hanem az összes, évszázadokon keresztül alkotott parlamenti végzemények, a százados nemzeti közszokás visszfénye, melynek helyes visszatükröztetése azért nehéz, mert az egyes főszervek múködése, melyekből az alkotmány áll, inkább mint időleges irány, sem mint élesen megvont hatalmi kör jelentkezik." (Concha, 1888, II. 177. o.).

$18 \mathrm{Az}$ angol jog az alapvető emberi jogok katalógusszerủ felsorolásától ezért is idegenkedik, azok elsődleges forrása ugyanis a common law (bírói jog), bár tartalmukra egyes jogi aktusok (Magna Charta, Petition of Rights, Bill of Rights, Habeas Corpus Act) is jelentős hatással bírtak. Az eltérő eredet talán a legfontosabb oka annak, hogy a 18-19. században az angol és a kontinentális „alapjogi katalógus” némiképp eltért egymástól (például a levéltitok, a tanszabadság, a vallásszabadság és a sajtószabadság kérdésében). Lásd még: Concha, 1888, II. 14-172. o.

19 E tekintetben talán a legfontosabb különbség a kontinentális országokhoz képest, hogy a törvény előtti egyenlőség, amely a kontinensen a polgárosodás egyik fô célkitüzése volt, a szigetországban már a középkor folyamán elismerést nyert. „[...] az angol társadalom századok óta a törvény előtti egyenlőség elvén nyugszik. Az angol egyéni szabadság bástyái, a Magna Charta óta, a szegényt és gazdagot, a hatalmas fơurat s az egyszerú parasztot egyaránt védelmezik, a törvény előtti jogegyenlőség az alkotmány alapvonása." (Concha, 1888, 121. о.).

20 Lásd: Coercion Acts. Elérhető: www.oxfordreference.com/view/10.1093/oi/authority.20110803095621949 (Letöltve:2020. június 10.). Az angol jogfelfogás szerint a kivételes hatalom gyakorlásának feltétele a Habeas Corpus Act (a törvényes eljáráshoz való jog) felfüggesztése volt. Az intézményről bővebben lásd: Concha, 1888, II. 172-174. o. 
teles eljárásban történő kezelését. ${ }^{21} \mathrm{~A}$ leggyakrabban ${ }^{22}$ idesorolt jogszabályok a 18. századból származnak, a legkorábbi ezek közül az alapvető törvényhozási hatásköröket érintő, a felkelésrôl és az adózásról szóló 1715. évi VIII. törvény, amely váratlan háborús helyzet esetén lehetôvé tette és szabályozta az uralkodó fenti tárgyakban való eljárását.

A kivételes hatalom szabályozásának ügye az 1848-49-es forradalom és szabadságharc időszakában vált központi témává, amikor mind az osztrák, mind a magyar kézben lévő területeken kivételes állapot bevezetésére került sor. Magyar részről az első kivételes hatalomról szóló törvényjavaslatok (egy képviselői indítványként, egy pedig a Deák Ferenc vezetésével múködő Igazságügyi Minisztérium által jegyzett előterjesztésként) is ekkor készültek. Mindkét - az 1848 júliusában benyújtott - javaslat a kivételes hatalom (korabeli elnevezéssel: az ostromállapot) átfogó szabályozását célozta. Általános szabályozás helyett azonban végül csak az igazságszolgáltatás területén a rögtönítélő bíráskodás törvényi szabályozására került sor 1849 elején. ${ }^{23}$ Bár törvényi szabályozása elmaradt, a rendkívüli helyzetek kezelése a gyakorlatban kormánybiztosok ${ }^{24}$ kiküldése útján történt.

\subsubsection{Kitekintés: az osztrák különleges jogrend érvényesülése Magyarországon (1848-1865)}

1848 októberében az osztrák-magyar ellentétek kiéleződésével az uralkodó királyi leirattal feloszlatta a magyar országgyúlést, egyúttal teljhatalmú királyi biztost nevezett ki a Magyar Királyság teljes területére, és deklarálta, hogy „Magyarország hadi törvények alá vettetik". ${ }^{25}$ A királyi biztos (báró Jellasics) kiűzését követően, 1848 novemberében herceg Windischgrätz kapott teljhatalmat, amit decemberben az új uralkodó, Ferenc József is megerősített. Windischgrätz 1848 decemberétől a - katonai igazgatásnak alárendelt - közigazgatás megszervezésére királyi biztosokat nevezett ki. Az alkotmányos szintú felhatalmazást majd csak az olmützi alkotmány biztosította 1849 tavaszán, ${ }^{26}$ amely a birodalmi gyúlés akadályoztatása esetén felhatalmazta a császárt ideiglenes szabályok megalkotására.

21 Összefoglalóan lásd: Tóth, 1982.

22 A 19. századi jogtudósok véleménye megoszlott az e körbe tartozó jogszabályokról, azok tartalmáról, egyáltalán a kivételes hatalom fennállásáról. Érdemes itt még megemlékezni Molnár Kálmán jogászprofesszor Kormányrendeletek címú monográfiájáról (1911) is, amely szintén foglalkozik a kérdéssel.

23 Lásd: 1849. évi I. törvénycikk a rögtönitélő hadi s polgári vegyes biróságok felállitása, szerkezete, eljárása, s itéletek alá tartozó esetek meghatározása tárgyában. Lásd még: Mezey, 2003.

24 A végrehajtó hatalom szervei és a törvényhozás elsősorban a különböző szervek közötti koordináció elősegítésére vagy rendkívüli helyzetek kezelésére gyakran biztosokat küldtek ki, akikre vélhetôen a korábbi királyi biztosok elnevezésének mintájára általában kormánybiztosként hivatkoztak. Az első biztosok kiküldésére még 1848 márciusában sor került. A kormánybiztosok 1848-49-es szabályozására és múködésére lásd Csizmadia Andor és Hermann Róbert munkáit.

25 Idézi: Tóth, 1982, 17. o.

26 Vö.: olmützi alkotmány 87. \$. Elérhető: www.verfassungen.at/at-18/verfassung49-i.htm (Letöltve: 2020. június 10.). 
Bár az olmützi alkotmányt 1851-ben hatályon kívül helyezték, ${ }^{27}$ az ostromállapot (katonai igazgatás) a gyakorlatban csak 1856 elején szűnt meg Magyarországon. Az 1860-61-es, a magyar alkotmányosság helyreállítását célzó kísérletek kedvezőtlen fogadtatását követően azonban az uralkodó újra a különleges jogrend bevezetése mellett döntött. Bár az 1861 októbere és 1865 júniusa között létező provizórium a korábbi ostromállapotnál enyhébb szabályozást eredményezett, a különleges jogrend egyik esetköreként kell számításba vennünk. ${ }^{28}$

\subsubsection{Kivételes hatalom a dualizmus korában}

A kiegyezést követően az Osztrák-Magyar Monarchia mindkét felében felmerült a kivételes hatalom szabályozásának igénye. ${ }^{29}$ Magyarországon azonban hosszú idő keresztül csupán eseti jelleggel, egyes törvényekhez kapcsolódva biztosították a kivételes hatalom lehetőségét, ugyanis „[...] törvényhozásunk egész szelleme tanúsítja, hogy hazánkban a szükségrendeleteknek csak igen szúk mérvben lehet jogilag helye". ${ }^{30} \mathrm{Az}$ elméletben szúk körünek tartott kivételek azonban a honvédelem és a közigazgatás területére estek, ${ }^{31}$ és a gyakorlatban akár jelentős mértékủ beavatkozást is lehetôvé tettek volna. ${ }^{32}$

\subsection{A különleges jogrend első átfogó magyar szabályozása: a kivételes hatalomról szóló 1912. évi LXIII. törvénycikk}

\subsubsection{A törvény keletkezése}

A századfordulón, a nagyhatalmak közti feszültségek növekedésével elsősorban katonai, hadügyi kérdésként került elötérbe a kivételes hatalom ügye. ${ }^{33} \mathrm{~A}$ kiegyezési törvény alapján ez úgynevezett közös ügynek számított, ${ }^{34}$ ezért a közös hadügyminisztérium megkeresései

27 Hatályon kívül helyezték 1851. 12. 31-én (Magyarországot illető Törvény- és Kormánylap 1852, 1. kötet 1. szám). 28 Lásd bővebben: Tóth, 1982, 33-34. 0.

29 Az osztrák szabályozást lásd lentebb. Magyarországon 1868-ban egy egyesületi és gyülekezési törvényjavaslat (a továbbiakban: Javaslat) készült, amely e jogok felfüggesztéséről is rendelkezett. A Javaslat - háború vagy belforrongás, illetve az egyesülési vagy gyülekezési jog nem rendeltetésszerủ használata esetén - az eljárásra az országgyưlés tájékoztatása mellett a belügyminisztert jogosította volna fel. A Javaslatra bővebben: Domaniczky, 2010.

30 Lásd: Kiss, 1886, 20. o.

31 A honvédelem területén a honvédség, illetve a népfelkelés határokon kívül történő felhasználása, közigazgatás területén pedig a kormány határozatainak végrehajtása volt az a kiemelt cél, amely a kivételes hatalom biztosítását indokolta. Vö.: 1868. évi XLI. tv., 1886. évi XX. tv., valamint 1870. évi XLII. és 1886. évi XXI. tv., illetve Kiss, 1886, 20. o. és Moskovitz, 1906, 25-27. o.

32 Például az 1905-1906-os válság idején, amikor a kormány egyébként is „[k]ivételes állapot kihirdetését javasolta..." (Katus, 2012, 562. o.).

33 Lásd bővebben: Mezey, 2016, 11-18. o.

34 Lásd: a magyar korona országai és az Ő Felsége uralkodása alatt álló többi országok között fennforgó közös érdekű viszonyokról, s ezek elintézésének módjáról szóló 1867. évi XII. törvénycikk. 
egy önálló magyar tervezet elkészítésének irányába hatottak. ${ }^{35}$ A kormány koncepciójának egyik legfontosabb eleme az volt, hogy a kivételes hatalom gyakorlását Magyarországon a katonai helyett polgári hatóságra kell bízni. ${ }^{36}$

A háború esetére vonatkozó kivételes intézkedésekről szóló 1912. évi LXIII. törvénycikket (a továbbiakban: Kit.) - mint arra már a cím is utalt - eredetileg a háború vagy arra történő előkészület időszakában szükséges rendkívüli intézkedések megalkotása céljából ${ }^{37}$ fogadta el a magyar országgyưlés. A tárgyi hatály - összevetve a Monarchia ciszlajtán részében létező szabályozással - kifejezetten szúk volt, csak a legszükségesebb területre (a háborús helyzetre és arra való felkészülésre) szorítkozott..$^{38}$ Azon belül viszont egy szigorúan korlátozott, valóban kivételes hatáskört konstituált: ez volt a kivételes hatalom.

\subsubsection{A kivételes hatalom korlátai}

A Kit. szerint tehát a kivételes hatalom: (a) háború vagy háborús előkészület ${ }^{39}$ időszakában; (b) kormányzati döntést követően; (c) a Kit. alapján; (d) a szükséges mértékben vehető igénybe. A kivételes hatalom létezése időben korlátozott: legkésőbb a háború befejezésével megszúnik. Ekkor a Kit. alapján tett intézkedések is hatályukat vesztik, azaz a már folyamatban lévő ügyekre nézve is azonnal a rendes törvényes állapot áll helyre. ${ }^{40} \mathrm{~A}$ kivételes hatalom alapján hozott intézkedések időbeli hatálya korlátozott és feltételes: ha a háború nem törne ki, legfeljebb négy hónapig maradhatnak hatályban, hacsak az országgyuulés ${ }^{41}$ jóvá nem hagyja öket. ${ }^{42}$

A kivételes hatalom alapján hozott intézkedések tárgyát, hatályát és a hatálybalépés időpontját a kormány állapítja meg, de ezeket az intézkedéseket a legszélesebb körben ismertetni kell: egyrészt az állampolgárokkal a hivatalos lapban való közzététel útján, illetve minden érintett községben a helyben szokásos módon; másrészt utólag az országgyưléssel,

$35 \mathrm{Az}$ 1912-es törvény megszületése tehát elsősorban nem organikus jogfejlődés eredményeként, hanem egy adott közjogi problémára adott válaszként értelmezhető. A szabályozás időszerúsége vitán felül állt, viszont a saját javaslat megalkotása a magyar szuverenitást demonstrálta. Az egyeztetési folyamat állomásaira és a magyar álláspont alakulására lásd: Galántai, 1981, 196-197. o. Továbbá lásd még: Kelemen, 2016.

36 Részletesen lásd: Galántai, 1981, 196-197. o.

37 Kit. 1. \$ (1) bekezdés.

38 „Az 1912:63. tc. világos intencióval megkonstruált törvényünk s különösen abból a szempontból méltányolható, hogy mint lehet a posszibilis garanciák szoros védőfala között is biztosítani a kormányhatalomnak azt a szabad kezet, azt a rugalmas postestast, mely háborús viszonyok között eminens érdekünk." (Felszeghy, 1914, 474. o.; Polner, 1914).

39 A Kit. törvényjavaslatának indokolása szerint a katonai elókészület az az időszak, „[...] a midőn a helyzet komolysága általánosan és kétségbevonhatlanul megállapitható" (Részletes indokolás az 1. \$-hoz).

40 Vö.: Kit. 1. \$ (2) bekezdés és 3. \$.

41 E tekintetben a kormány államérdekre hivatkozással kérheti a vita mellőzését (vagyis a gyorsított országgyưlési döntéshozatalt). Lásd: Kit. 4. \$(4) bekezdés.

42 Lásd: Kit. 1. \$ (3) bekezdés. 
amelynek a „kivételes hatalom igénybevételét, valamint azt, hogy a kivételes hatalomból folyó intézkedések mely területre terjednek ki [...] a legközelebbi ülésben be kell jelenteni”.43

\subsubsection{A kormánybiztosok hatásköre}

Az 1848-49-ben a gyakorlatban bevált kormánybiztosi intézmény Kit.-be történő beépítése jelzi, hogy a sietség ellenére az elôterjesztő a magyar jogi hagyományoknak is megfelelő tervezet készítésére törekedett. A kormánybiztos itt már egyértelmú feladat- és hatáskörökkel rendelkezett, ugyanakkor teljhatalmát a jogalkotó több eszközzel - így például az intézkedései ellen biztosított jogorvoslati joggal - korlátok közé szorította.

A Kit.-ben rögzített felhatalmazáson alapuló közigazgatási feladatok végrehajtására Magyarországon a kormány, Horvát-Szlavónországokban a bán kormánybiztosokat ${ }^{44}$ nevezhet ki. ${ }^{45}$ Kormánybiztosok „csak magyar honos polgári egyének” lehetnek. ${ }^{46} \mathrm{~A}$ kormánybiztosok a kormánynak közvetlenül alárendelve múködnek, de az illetékes katonai parancsnokokkal összhangban kötelesek eljárni. A kormánybiztosok illetékességi területét a kormány állapítja meg: állandó székhely esetén egy vagy több törvényhatóság területére terjed ki, a katonai parancsnok mellé kirendelt kormánybiztos illetékessége viszont a katonai parancsnok teljes múködési területére is kiterjedhet. ${ }^{47}$

Feladatuk általánosságban, hogy „szükség esetén a közrend és a közbiztonság fenntartásáról gondoskodjanak, és hogy azokat a rendes közigazgatási intézkedéseket is megtegyék, amelyek a hadviselés sikere érdekében szükségesek". ${ }^{48}$ Ennek érdekében közvetlenül utasíthatják a törvényhatósági alkalmazottakat, az állami erdészet személyzetét, a rendfenntartó erők (csendőrség és rendőrség), valamint a pénzügy- és a határőrség alkalmazottait, akik a kormánybiztostól a Kit. alapján kapott feladatokat soron kívül kötelesek végrehajtani. E közegek az illetékes miniszter jóváhagyásával hatáskörükön kívüli feladatokra is igénybe vehetők. ${ }^{49} \mathrm{~A}$ kormánybiztos intézkedései azonnal végrehajtandók, viszont velük szemben

43 Lásd: Kit. 2. \$, valamint Részletes indokolás a 2. \$-hoz. Bár a Kit. csak az állampolgárok esetében írja elő a kormány tájékoztatási kötelezettségét, „ha intézkedéseit kiterjeszti, korlátolja vagy hatályukat megszünteti”, a törvénycikk és a törvényjavaslat indokolásából a jogalkotónak a legszélesebb nyilvánosság biztosítását célzó szándéka olvasható ki, vagyis ez esetben is szükséges az országgyûlés utólagos tájékoztatása.

44 A kormánybiztosi intézménynek komoly hagyományai voltak a magyar történelemben, illetve a közjogban. Az 1848-49-es szabadságharc alatti múködésükre lásd bővebben: Hermann, 1998.

45 Vö.: Kit. 4. \$ (1) és (12) bekezdés.

46 Vagyis a Magyar Királyság állampolgárai, akik nem tagjai a hadseregnek.

47 Kit. 4 . $\$(3)-(4)$ bekezdés.

48 Vö.: Kit. 4 . $\$(2)$ bekezdés.

49 A késlekedő, nem engedelmeskedő alkalmazottat a kormánybiztos felfüggeszthette, másokkal helyettesíthette, a feladat ellátására alkalmatlannak vélt személyt pedig rendelkezési állományba helyezhette. Ezen intézkedések hatálya a rendkívüli állapot megszúnéséig tartott, de a vétkes magatartása miatt felfüggesztett alkalmazott ellen hivatalból fegyelmi eljárást is kellett indítania (az erre egyébként általában hatáskörrel rendelkező személyeknek). Vö.: Kit. 4. \$(5)-(10) bekezdés. 
a Kit. jogorvoslati jogot biztosított az illetékes miniszterhez. A megtámadott döntés ellen annak meghozatalától számított 15 napon belül lehetett fellebbezéssel élni. ${ }^{50}$

\subsubsection{A kivételes hatalom által érintett jogágak, jogszabályok}

A Kit. érdemi része mai jogi szakszóval nevezve alapjogi korlátozások lehetőségét teremti meg (5-12. \$), illetve egyes cselekmények vagy mulasztások szankcionálását vagy azok általában szokásos büntetési tételének megemelését teszi lehetővé (15., 18-30. \$). ${ }^{51}$

A Kit. által lehetôvé tett alapjogi korlátozásokat az alábbi táblázat szemlélteti.

\begin{tabular}{|c|l|}
\hline $\begin{array}{c}\text { Helyi } \\
\text { önkormányzáshoz } \\
\text { való jog }\end{array}$ & $\begin{array}{l}\text { (a) A kormány rendelettel ideiglenesen hatályon kívül helyezheti az ön- } \\
\text { kormányzati szabályrendeletek rendőri természetú rendelkezéseit, ezek } \\
\text { helyére belügyminiszteri vagy kormánybiztosi rendelettel ideiglenes sza- } \\
\text { bályozás alkotható; (b) a belügyminiszter a törvényhatósági bizottság vagy } \\
\text { a községi (rendezett tanácsú városi) képviselő-testület minden határozatát, } \\
\text { amely hadviselési érdeket sért vagy a közrend és a közbiztonság fenntar- } \\
\text { tását veszélyezteti, hivatalból megsemmisítheti, és „amennyiben a fenti } \\
\text { szempontból intézkedésre szükség van, ezt saját hatáskörében megteheti” } \\
\text { [Kit. 5. \$ (2)-(3) bekezdés]. }\end{array}$ \\
\hline $\begin{array}{c}\text { Jogorvoslathoz } \\
\text { való jog }\end{array}$ & $\begin{array}{l}\text { A helyi önkormányzatok szabályalkotási jogának elvonásával kapcsolatos } \\
\text { rendelkezések és intézkedések ellen jogorvoslatnak nincs helye [Kit. 5. \$ } \\
\text { (3) bekezdés]. }\end{array}$ \\
\hline $\begin{array}{c}\text { Külföldre utazáshoz } \\
\text { való jog }\end{array}$ & $\begin{array}{l}\text { A kormány az útlevél-kiállítás jogát az állam egész területén vagy egy } \\
\text { részén a törvény szerint eljáró hatóságok hatásköréból kiveheti, és Magyar- } \\
\text { országon a belügyminiszter, Horvát-Szlavónországokban a bán hatás- } \\
\text { körébe utalhatja [Kit. 6. \$ (1) bekezdés]. }\end{array}$ \\
\hline
\end{tabular}

50 Vö.: Kit. 4. \$ (11) bekezdés, valamint Részletes indokolás a 4. \$-hoz. A két szöveg összevetéséből következően fellebbezéssel az érintett élhetett.

51 A törvény biztosítja továbbá a rendkívüli állapot kezeléséhez szükséges pénzügyi mozgásteret (a hadviseléshez szükséges költségek megelőlegezését) is a kormány számára, amíg az országgyưlés azokat meg nem állapítja. Lásd: Kit. 17. \$. 


\begin{tabular}{|c|c|}
\hline $\begin{array}{l}\text { Szabad mozgás } \\
\text { és tartózkodási } \\
\text { hely szabad } \\
\text { megválasztása }\end{array}$ & 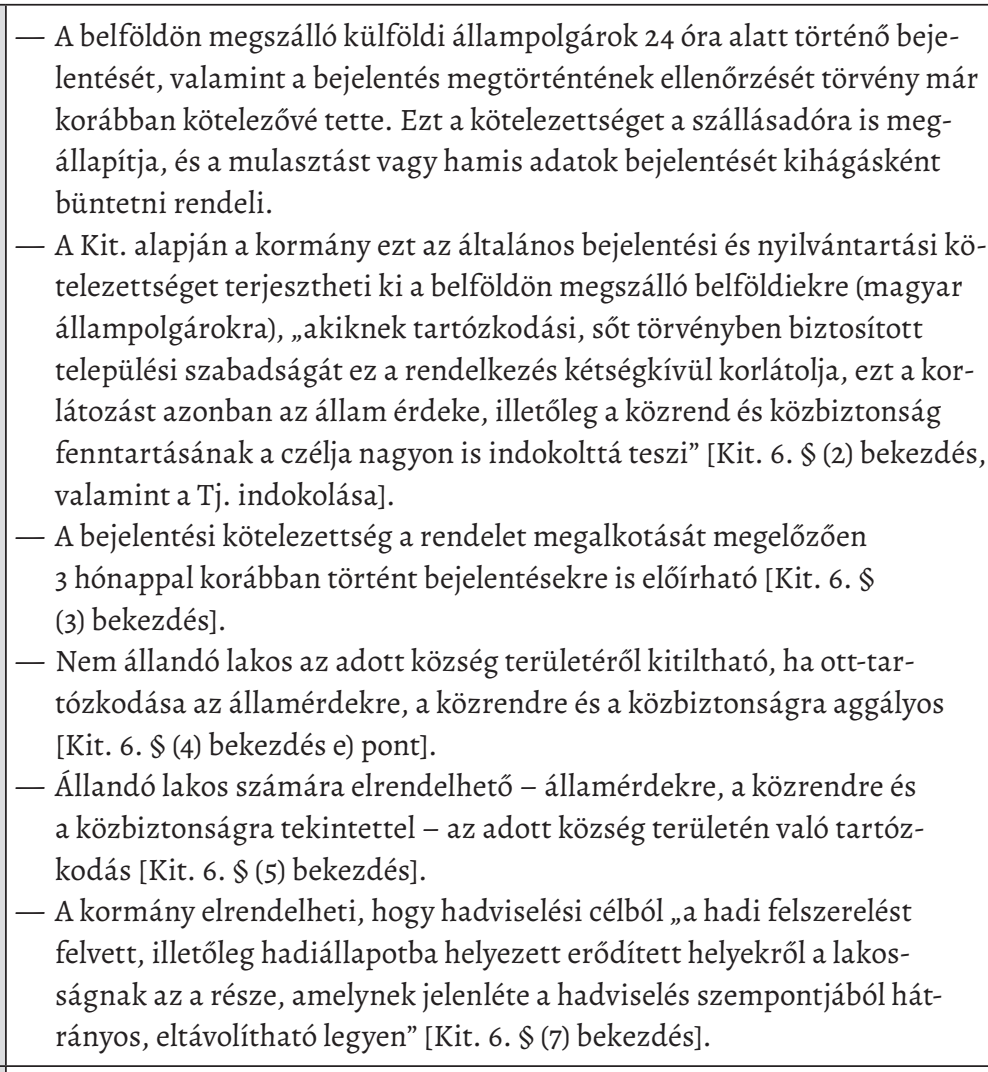 \\
\hline Tulajdonhoz való jog & $\begin{array}{l}\text { A kormány korlátozhatja vagy megtilthatja olyan tárgyak birtoklását } \\
\text { vagy használatát, amelyek a hadviselés érdekeinek vagy a közrendnek } \\
\text { és a közbiztonságnak veszélyeztetésére használhatók (fegyverek, lőszer, } \\
\text { lőpor, robbantó anyagok stb.), és az ily tárgyak beszolgáltatását elrendelheti } \\
\text { [Kit. 7. \$ (1) bekezdés]. }\end{array}$ \\
\hline $\begin{array}{l}\text { Vállalkozáshoz való } \\
\text { jog }\end{array}$ & $\begin{array}{l}\text { Ha tartani lehet attól, hogy egyes fogyasztási cikkek ára a katonaság be- } \\
\text { vonulása, elvonulása, katonai előkészületek vagy háború nyomán arányta- } \\
\text { lanul és indokolatlanul emelkedni fog, a kormány hatósági árat rendelhet el } \\
\text { [Kit. 7. \$ (4)-(5) bekezdés]. }\end{array}$ \\
\hline $\begin{array}{l}\text { Személyi } \\
\text { szabadsághoz } \\
\text { valójog }\end{array}$ & $\begin{array}{l}\text { Ha az a gyanú merül fel, hogy valaki a hadviselés érdekeinek vagy a köz- } \\
\text { rendnek és a közbiztonságnak veszélyeztetésére használható tárgyat (fegy- } \\
\text { verek, looszer, lőpor, robbantó anyagok stb.) jogosulatlanul tart birtokában, } \\
\text { ennek megállapítása végett nála személymotozás és házkutatás tartható. } \\
\text { A jogosulatlanul birtokolt tárgyakat el kell kobozni [Kit. 7. \$ } \\
\text { (2)-(3) bekezdés]. }\end{array}$ \\
\hline
\end{tabular}




\begin{tabular}{|c|c|}
\hline $\begin{array}{l}\text { Magántitok védel- } \\
\text { méhez való jog }\end{array}$ & $\begin{array}{l}\text { A kormány a nemzetközi egyezmények korlátai közt megteheti mindazokat } \\
\text { az intézkedéseket, amelyek szükségesek avégből, hogy a postai, távirdai } \\
\text { és távbeszélő-forgalom és -érintkezés a hadviselés érdekeinek megóvása } \\
\text { céljából ellenőrzés alá vétessék [Kit. 8. \$ (1) bekezdés]. }\end{array}$ \\
\hline $\begin{array}{l}\text { Szabad vélemény- } \\
\text { nyilvánítás joga }\end{array}$ & $\begin{array}{l}\text { — A kormány elrendelheti, hogy az időszaki lapoknak és más sajtótermé- } \\
\text { keknek a sajtöügyi közvádlóhoz benyújtandó sajtórendészeti köteles- } \\
\text { példányait a szétküldés előtt kell a legközelebbi ügyészségnek, illetve } \\
\text { rendőrségnek kézbesíteni, és hogy a szétküldés, amennyiben korábban } \\
\text { meg nem engedik, időszaki lapoknál csak a sajtórendészeti kötelespéldány } \\
\text { kézbesítésétől számított három óra múlva, más sajtótermékeknél a kézbe- } \\
\text { sítés napjától számított egy hét múlva veheti kezdetét. } \\
\text { — Ha az illetékes ügyészség vagy rendôrség arról győződik meg, hogy } \\
\text { valamely sajtótermékkel a hadviselés érdekeit érintố búncselekmény va- } \\
\text { lósul meg, a sajtótermék szétküldését megtilthatja, ám ezzel egyidejúleg } \\
\text { köteles a tilalom megszegésének a 25. \$-ban megállapított (büntetőjogi) } \\
\text { következményeit a sajtótermék elóállítójával közölni. } \\
\text { — A kormány egyes belföldi időszaki lapok megjelenését és ter- } \\
\text { jesztését - amennyiben közleményeik a hadviselés érdekeit } \\
\text { veszélyeztetik - betilthatja. } \\
\text { — A kormány a külföldről érkező sajtótermékeket rendeltetési helyülkre } \\
\text { érkezésük előtt ellenőrizheti, és amennyiben tartalmuk a hadviselés } \\
\text { érdekeire veszélyes, azokat lefoglaltathatja. } \\
\text { — Külföldi időszaki lapok behozatala és terjesztése egészen is eltiltható } \\
\text { [Kit. 11. \$ (1)-(5) bekezdés]. }\end{array}$ \\
\hline Egyesülési jog & $\begin{array}{l}\text { Ha az „állam biztonsága szempontjából szükséges”: } \\
\text { — új egyesületek vagy fiókegyesületek alakítása megtiltható; } \\
\text { — már meglevő egyesületek vagy fiókegyesületek gyưlése ellenőrizhető, } \\
\text { múködésük korlátozható vagy felfüggeszthető; } \\
\text { — a hatósági ellenőrzés alatt nem álló kereskedelmi társaságok vagy más } \\
\text { társulatok, pénztárak rendőri ellenőrzés alá vonhatók, ha az a gyanú } \\
\text { merül fel, hogy múködésük jogszabályba vagy alapszabályukba ütközik, } \\
\text { avagy államellenes irányzatot vesz. A gyanú beigazolódása esetén gyû- } \\
\text { léseik betilthatók vagy feloszlathatók, jogellenes határozataik végre- } \\
\text { hajtása pedig megtiltható [Kit. 9. \$(1) bekezdés]. }\end{array}$ \\
\hline Gyülekezési jog & $\begin{array}{l}\text { Ha az állam biztonsága érdekében szükséges, a kormány politikai jellegú } \\
\text { népgyúlések, felvonulások, körmenetek stb. tartását megtilthatja, és } \\
\text { - a közigazgatási hatóságok gyûléseinek kivételével - egyéb gyûlések } \\
\text { tartását hatósági engedélytől teheti függóvé, tekintet nélkül arra, hogy } \\
\text { bejelentésül rendes körülmények között kötelező-e, vagy sem [Kit. 10. \$ } \\
\text { (1) bekezdés]. }\end{array}$ \\
\hline
\end{tabular}




\begin{tabular}{|c|l|}
\hline $\begin{array}{c}\text { Polgári eljárásjogi } \\
\text { garanciák }\end{array}$ & $\begin{array}{l}\text { A kormány a magánjogi követelések érvényesítése tekintetében - ideértve } \\
\text { a váltólöövetelések érvényesítését is -, továbbá a polgári peres és nem peres } \\
\text { eljárás és általában a polgári igazságszolgáltatás, végül a jegybank ügyvitele } \\
\text { tekintetében rendkívüli intézkedéseket tehet, és evégból a fennálló törvé- } \\
\text { nyektôl eltérő rendelkezéseket is állapíthat meg [Kit. 16. \$]. }\end{array}$ \\
\hline $\begin{array}{c}\text { Büntetőjogi } \\
\text { garanciák }\end{array}$ & $\begin{array}{l}\text { Kit. alapján: (a) egyes büntetőeljárási szabályok kormány- vagy miniszteri } \\
\text { rendelettel is megalkothatók; (b) egyes búncselekmények a búnvádi per- } \\
\text { rendtartástól (Bp.) eltérô szabályok alapján is elbírálhatók; (c) „a polgári } \\
\text { büntető bíróságok akkor is eljárhassanak, ha a Bp. szerint illetékes- } \\
\text { séggel nem is bírnak” [Kit. 12. \$ 1-4. pontok, 31. \$ és Részletes indokolás } \\
\text { a 12.\$-hoz és a 31. \$-hoz]. }\end{array}$ \\
\hline
\end{tabular}
1. táblázat
Alapjog-korlátozások a Kit.-ben
Forrás: a szerző saját összeállítása a Kit. alapján

A Kit. által bevezetett szankciók alapvetően háromirányúak voltak: kihágási (szabálysértési) tényállások szigorítása, bővítése; büntetőjogi szigorítások létező tényállások kiegészítése, új tényállások megalkotása révén; rendes eljárások statáriális körbe vonása.

A kihágási tényállások egy része az alapjogi korlátozásokhoz kapcsolódik (6-7., 9-11. \$), de a Kit. tartalmaz egy generális klauzulát is a kormánybiztos intézkedéseinek nyomatékosítása érdekében [15. \$ (1) bekezdés]. A büntetőjogi szigorítások célja az állam érdekeinek háború idején történő „hathatós büntetőjogi védelme”, ${ }^{52}$ ennek érdekében a törvény több helyen szigorítja és pontosítja a büntető- (1878. évi V. törvény) és a kihágási (1879. évi XL. törvény) törvényeket. A rendes eljárások statáriális körbe vonása körében a Kit. anyagi és alaki szabályoktól való eltéréseket is engedett a kormány számára, amikor lehetővé tette, hogy egyes büncselekményekre a rögtönítélő bíráskodás szabályait alkalmazzák, ${ }^{53}$ másrészt e szabályokat a szokásostól eltérôen rendeleti úton is megalkothassák. ${ }^{54}$

\subsubsection{A törvény a gyakorlatban: a kivételes hatalom alkalmazása és kiterjesztése (1914-1918)}

A szarajevói merényletet követő válsághelyzet eszkalálódásával az Osztrák-Magyar Monarchia a háborús előkészület (1.2.2. pont) szakaszába lépett. A jogforrások alapján

52 Lásd: Kit. Részletes indokolás a II. fejezethez.

53 Lásd: Kit. 12. \$4 pont és Részletes indokolás a 12. \$-hoz.

54 Lásd: Kit. 31. \$ és Részletes indokolás a 31. \$-hoz, valamint a polgári büntetőbíráskodás alá tartozó egyéneknek a honvéd büntetőbíráskodás alá helyezéséről szóló 5491/1914. ME rendelet [Rendeletek Tára (a továbbiakban: RT) 1914. 1990.] és a gyorsított búnvádi eljárás szabályairól szóló 12002/1914. IM rendelet (RT 1914. 1976-1989.), továbbá a gyorsított bưnvádi eljárás életbeléptetéséról szóló 5488/1914. ME rendelet (RT 1914. 1434-1437.). 
a Kit. alkalmazására először az 1914. július 26-i rendeletcsomag kapcsán került sor. ${ }^{55}$ E rendeletcsomag egyes elemeinek hatályát aztán 1914. augusztus 1-jével kiterjesztették,, ${ }^{56}$ és ezzel megkezdődött a Kit. felhatalmazása alapján készült rendeletek kiadása. A háború állandósulásával a Kit. és „rendeletbokrai” a hétköznapi élet egyre több területét fonták át. ${ }^{57}$ A törvény szinte állandó hivatkozási alappá vált, ${ }^{58}$ ezért a szövegét a gyakorlati tapasztalatok alapján és az újonnan felmerülő helyzetek kezelése érdekében a háború ideje alatt többször is módosították. ${ }^{59}$

\subsubsection{Kitekintés: a különleges jogrend szabályozása az Osztrák-Magyar Monarchia másikfelében (1867-1918)}

Amíg Magyarországon a kivételes hatalom átfogó szabályozására csak a dualizmus utolsó évtizedében, akkor is csak a honvédelem érdekeihez kapcsolódóan került sor, Ausztriában a kiegyezést követően kibocsátott alaptörvények már általános jellegú szabályokat tartalmaztak a különleges jogrendre. ${ }^{60} \mathrm{~A}$ máig hatályos, a polgárok alapvetó jogairól szóló törvény ${ }^{61}$ az egyes jogok korlátozásával kapcsolatban a részletszabályok kidolgozását külön törvényre bízta, amely 1869-ben el is készült. ${ }^{62}$

A törvény egészen a világháború végéig hatályban volt, ${ }^{63} 1914$ májusa és 1917 eleje között ez alapján kormányozták a Monarchia osztrák felét. ${ }^{64}$

55 Lásd: RT 1914. 1410-1413.

56 Lásd: RT 1914. 1448-1450.

57 Vö. például a házasságkötésre vonatkozó kivételes intézkedésekről szóló 647/1915. ME rendelet (RT 1915. 7072.), illetve az Élesztőipari Bizottság alakításáról szóló 119/1918. ME rendelet (RT 1918. 3-6.).

58 Lásd például a háború fogalmát az 1915. évi XIX. törvényben.

59 Vö.: 1914. évi L. tv., 1915. évi XIII. tc., 1916. évi IV. tv., 1917. évi VII. tv.

60 Lásd: az 1861. február 26-i alaptörvényt módosító államalaptörvény 14. \$ (korabeli magyar fordítását lásd: Pesti Napló 1867. 12. 28. 96.).

61 Korabeli magyar fordítását lásd: Pesti Napló 1867. 12. 29. 99., valamint Deák, 2001.

62 Ez volt az 1869. május 5-i törvény, eredeti szövegét lásd: Reichsgesetzblatt 1869/31. 303-306., magyar nyelvú összefoglalását Polner, 1917, 38-40. o., valamint Tóth, 1967.

63 A magyar fél részére tehát viszonylag korán rendelkezésre állt volna egy szabályozási minta, amelynek alkalmazása azonban az alapjogok törvény általi szabályozását is szükségessé tette volna, amellyel azonban a törvényhozás az egész korszakban adós maradt. Az alapjogi szabályozással - amely tehát a kivételes hatalom szabályozásának előfeltétele is lett volna - kapcsolatos osztrák és magyar felfogás különbözőségét jól demonstrálja Eöttevényi, é. n. Az egyesülési és gyülekezési jog tekintetében lásd még: Domaniczky, 2010; Domaniczky, 2012.

64 Lásd bővebben: Szinai, 1986; Murber, 2018. 


\subsection{A különleges jogrend továbbélése a két háború korában}

\subsubsection{Biztos pont a válságban (1918-1922)}

A háború végén a Károlyi-kormány a Kit.-et - az 1918. november 16-i néphatározatnak megfelelően - kétféleképpen használta. ${ }^{65}$ Egyrészt megkezdte a szabadságjogokkal kapcsolatban bevezetett korlátozások (például egyesülési, gyülekezési jog, sajtószabadság) feloldását, ${ }^{66}$ másrészt viszont továbbra is élt a Kit. által biztosított felhatalmazásokkal a már létező szabályozások fenntartásához. ${ }^{67}$ A szabadságjogokra vonatkozó korlátozásokat a Friedrich-kormány visszaállította. ${ }^{68}$

A Kit. és a hozzá kapcsolódó joganyag rendeltetése szerint a háború végéig maradt volna hatályban, de a békeszerződés megkötéséhez közeledve a hatályát meghosszabbították. Az erről szóló 1920. évi VI. törvény ${ }^{69}$ a meghosszabbítás lehetséges időtartamát a „békeszerződés megerősítésétől” számított egy évben határozta meg, amely három hónappal még meghosszabbítható volt. ${ }^{70} \mathrm{~A}$ békeszerződés becikkelyezésére azonban csak az 1921. évi XXXIII. törvénnyel került sor, amely 1921. július 26 -án lépett hatályba, ${ }^{71}$ tehát az 1920-as törvény alapján a Kit.-féle joganyag legkésőbb 1922 júliusának végéig maradhatott volna hatályban.

Fontos megjegyezni, hogy a kivételes hatalom alapján keletkezett joganyag hatályának fenntartását csak részben indokolta a békébe történő átmenet zökkenőmentessége. Sokkal inkább arról volt szó, hogy a különleges jogrend a számtalan nehézséggel küzdő ország újraszervezését könnyítette meg. Erre utalt az 1920. évi VI. törvény, amikor a kivételes hatalom fenntartásának alapjául szolgáló érdeket a belső rend, a közbiztonság és a külpolitikai érdekek biztosításában határozta meg. ${ }^{72}$ Fontos szemléletbeli változásnak számít az is, hogy a jogalkotó felismerte, hogy egyes jogviszonyok a háború időszakában (vagy azt követően)

65 Fontos kiemelni, hogy a Károlyi-kormány és a Nemzeti Tanács megvizsgálta, hogy a régi rend által alkotott jogforrásokra mennyiben támaszkodhat. Károlyi maga a „tiszta jogalap” álláspontjára helyezkedett, ennek köszönhetően fennállása alatt folyamatosan élt a Kit. által biztosított felhatalmazásokkal. Lásd bővebben: Schönwald, 1969, 233-234. o.

66 Vö.: 4802/1918. ME rendelet (RT 1918. 2198-2199.), 4969/1918. ME rendelet (RT 1918. 2199-2200.), 4970/1918. $\mathrm{ME}$ rendelet ( $\mathrm{RT}$ 1918. 2200.).

67 Vö. például a burgonya, tengeri és árpa szesztermeléshez való felhasználásának eltiltásáról szóló 4878/1918. ME rendeletet vagy a fa- és faszénkészletek bejelentésére és nyilvántartására, valamint felhasználásuk és forgalomba hozataluk szabályozására vonatkozó 1851/1917. ME számú és 2086/1917. ME számú rendeletek egyes intézkedéseinek módosításáról szóló 5034/1918 ME rendeletet (RT 1918. 2197, 2201.).

68 Vö.: 5499/1919. ME rendelet (RT 1919. 874-875.), 5084/1919. ME rendelet (RT 1919. 729-730.).

69 Hatályba lépett: 1920. május 13.

70 Lásd: a háború esetére szóló kivételes hatalom meghosszabbításáról szóló 1920. évi VI. törvény 1. \$.

71 Lásd: a trianoni békeszerződés életbeléptetéséről szóló 7200/1921. ME rendelet (RT 1921. 241-242.).

72 Lásd: 1920. évi VI. törvény $1 . \$$ (2) bekezdés. 
oly mértékben változtak meg, hogy az eredeti állapot visszaállítása (az összes Kit.-tel kapcsolatos jogszabály hatályon kívül helyezése) már nem lehetséges. ${ }^{73}$

\subsubsection{A kivételes hatalom állandósulása (1923-1939)}

Az 1920. évi VI. törvényből is kiolvashatóan a Bethlen-kormánynak szüksége volt a kivételes hatalomra, még a törvényben biztosított határidő után is, ezért végül egy költségvetési törvénybe beépítve tette lehetővé a különleges jogrendre épült szabályozás fenntartását. ${ }^{74}$ Az 1922 augusztusában hatályba lépő, az 1922/23. költségvetési év első hat hónapjában viselendő közterhekről és fedezendő állami kiadásokról szóló 1922. évi XVII. törvény 6. \$-a egyszerre írta elő - szoros határidőhöz kötve - a Kit.-féle joganyag deregulációját, ${ }^{75}$ illetve adott idôbeli korlát nélküli, ám a Kit.-re épülő rendeletalkotási jogot a kormánynak a „békeszerződés végrehajtása vagy a békeszerződés rendelkezései következtében előállott helyzet rendezése céljából". ${ }^{76}$

A Kit.-féle joganyag első deregulációja ezt követően 1923-ban megtörtént, ${ }^{77}$ de a korszak végén, az 1939-es honvédelmi törvény ${ }^{78}$ hatálybalépéséhez kapcsolódva még egy deregulációs hullám következett, és a kormány végül számos (közel száz), Kit. alapján hozott rendeletet továbbra is hatályban tartott. ${ }^{79}$ Ezekre nézve a Hvt. 1939 megengedte, hogy a kormány tetszőlegesen módosítsa és kiegészítse azokat. ${ }^{80}$

Meg kell jegyezni, hogy a gazdasági világválság kezelésére - a „gazdasági és hitelélet rendjének megóvása" érdekében - a kormány törvénnyel egy, a Kit.-hez képest szúkebb körû́ felhatalmazást is kapott 1931-ben. ${ }^{81}$

73 Vö.: 1920. évi VI. tv. 2. \$. A háborús joganyag hatályon kívül helyezése vagy hatályban tartása valamennyi hadviselő államban problémát okozott. A kérdésre országonként eltérő válaszok születtek (például Magyarország és Új-Zéland a hatályban tartás, Ausztrália a hatályon kívül helyezés mellett döntött).

74 Lásd még: Takács, 1973.

75 Lásd: 1922. évi XVII. tv. 1. \$(1)-(2) bekezdés.

76 Lásd:1922. évi XVII. tv. 1. \$(3) bekezdés.

77 Lásd: a kivételes hatalom alapján kibocsátott egyes rendeletek hatályának megszúnéséről szóló 960/1923. ME rendelet (RT 1923. 29-38.). Az 1939-es dereguláció alkalmával a jogalkotó utalt arra, hogy a 6976/1922. ME rendelet készítésekor a jogszabályok listájába hiba csúszott, ezt 1939-ben próbálták korrigálni (vö.: RT 1939. 282. 2-3. \$).

78 A honvédelemról szóló 1939. évi II. törvény (a továbbiakban: Hvt. 1939).

79 Lásd: a háború esetére szóló kivételes intézkedésekről alkotott törvények, valamint a kivételes hatalom meghosszabbításáról és kiterjesztéséről szóló törvényi rendelkezések alapján kibocsátott, illetőleg fenntartott rendeletek közzétételéról szóló 8270/1939. ME rendelet (RT 1939. 1281-1355.).

80 Lásd: Hvt. 1939232 . \$ (3) bekezdés.

81 Lásd: a gazdasági és hitelélet rendjének, továbbá az államháztartás egyensúlyának biztosításáról szóló 1931. évi XXVI. törvény, amelyet egészen 1944. december 31-ig időről időre folyamatosan meghosszabbítottak (utoljára: 1944. évi IV. tv.). 


\subsubsection{A különleges jogrend újabb szabályozása: a honvédelemröl szóló 1939. évi II. törvény}

Az újabb konfliktushelyzet kapujában került sor a honvédelemról szóló 1939. évi törvény megalkotására, amely végül a Kit.-et és az azt módosító valamennyi törvényt, továbbá a Kit. hatályát fenntartó törvényi rendelkezéseket is hatályon kívül helyezte..$^{82}$ A Hvt. 1939 ugyanakkor lehetôvé tette a Kit. alapján létrejött jogszabályok további hatályban tartását is, a Teleki-kormány deregulációs rendelete e felhatalmazás alapján készült (1.3.2. pont). ${ }^{83}$

A Hvt. 1939 egyúttal újrakodifikálta a kivételes hatalom intézményét. ${ }^{84} \mathrm{~A}$ kivételes hatalomnak a honvédelmi törvénybe való inkorporálása rendszerektől függetlenül hosszan tartó hagyományt teremtett. ${ }^{85} \mathrm{~A}$ Hvt. 1939 - a Kit. alkalmazása során, több mint két évtized alatt összegyưlt tapasztalatokra építve ${ }^{86}$ - a korábbinál jóval tágabb körben vonta meg a kivételes hatalom korlátait.

Alapesetben a Hvt. 1939 szerint a kormány kivételes hatalommal élhet: háború vagy az országot közvetlenül fenyegetô háborús veszély idején; a törvényhozás további rendelkezéséig; a szükséges mértékben, de a Hvt. 1939-ben meghatározott rendelkezések révén. ${ }^{87}$ Ez alól kivételként, „ha a késedelemben veszély van”, a Hvt. 1939 egy tág felhatalmazást is biztosít a kormány részére: a honvédelem érdekében; a közigazgatási, magánjogi, eljárási és a törvényhozás hatáskörébe tartozó egyéb intézkedések meghozatalára. ${ }^{88} \mathrm{E}$ tág felhatalmazással szemben a Hvt. 1939 egy tárgyi ${ }^{89}$ és eljárási ${ }^{90}$ korlátot állapít meg. A kivételes hatalom általános korlátjaként a Hvt. 1939 rögzíti, hogy elrendelése négy hónapra szólhat, és azt csak az országgyúlés hozzájárulásával lehet alkalmanként négy hónappal meghosszabbítani.91 A Hvt. 1939 ugyancsak a Kit.-re épülő jogszabálybokrok tapasztalataiból okulva törvényi felhatalmazást biztosít a kormány részére a háborút követő átmeneti időszak intézkedéseinek megtételére.92 A Hvt. 1939 fenntartotta továbbá a kivételes hatalommal kapcsolatos büntetőjogi szabályozásra vonatkozó igényét, bár ezek a rendelke-

82 Lásd: Hvt. 1939 231. \$ (2) bekezdés.

83 Hvt. 1939 232. \$, valamint 8270/1939. ME rendelet (RT 1939. 1281-1355.).

84 Hvt. 1939141-170. \$.

85 Vö.: a honvédelemről szóló 1960. évi IV. tv., 1976. évi I. tv., 1993. évi CX. tv., 2004. évi CV. tv., 2011. évi CXIII. tv. 86 A tapasztalatok beépítését - számos esetben a konkrét jogszabályi helyek megjelölése mellett - egyébként a Hvt. 1939 javaslatához készült indokolás is hangsúlyozza. Lásd bővebben: Hvt. 1939 javaslatának Részletes indokolása (a 141-170. \$-hoz).

87 Hvt. 1939141. \$ (1) bekezdés.

88 Hvt. 1939141. $\$(2)$ bekezdés.

89 A Hvt. 1939141. \$ (3) bekezdése szerint az állami főhatalom szervezetét és múködését érintő, a törvényhatósági és községi önkormányzat rendszerét módosító vagy megszüntető rendelkezéseket kibocsátani, továbbá az egyébként fennálló törvényi felhatalmazásokon túlmenően anyagi büntetőjogi szabályokat megállapítani nem lehet.

90 A Hvt. 1939141. \$ (3) bekezdése szerint a (2) bekezdés alapján kibocsátott rendeleteket haladéktalanul be kell mutatni az alábbi rendelkezések értelmében az országgyúlés mindkét házából alakítandó országos bizottságnak, amelynek összehívása iránt elnökei nyolc napon belül intézkednek.

91 Hvt. 1939141. $\$(8)$ bekezdés.

92 Hvt. 1939141. $\$(9)$ bekezdés. 
zések a Kit.-tel ellentétben a törvényen belül nem különülnek el.93 A Hvt. 1939 szankciórendszerrel kapcsolatos legfontosabb újítása a kormánybiztos kihágási jogkörrel történő felruházása volt.94

A Hvt. 1939 által meghatározott, kivételes hatalom révén szabályozható területeket terjedelmi okok miatt táblázatos formában tekintjük át.

\begin{tabular}{|c|c|c|c|c|}
\hline $\begin{array}{c}\text { Közigazgatással } \\
\text { kapcsolatos } \\
\text { hatásköröl }\end{array}$ & $\begin{array}{l}\text { Rendészeti } \\
\text { hatáskörölk }\end{array}$ & $\begin{array}{c}\text { Pénzügyi } \\
\text { hatáskörölk }\end{array}$ & $\begin{array}{l}\text { Igazságszolgálta- } \\
\text { tással kapcsolatos } \\
\text { hatáskörök }\end{array}$ & $\begin{array}{c}\text { Egyéb kivételes } \\
\text { hatáskörök }\end{array}$ \\
\hline $\begin{array}{l}\text { közigazgatási } \\
\text { szervezet } \\
\text { módosítása } \\
\text { (Hvt. 142.\$) }\end{array}$ & $\begin{array}{l}\text { útlevéllel } \\
\text { kapcsolatos } \\
\text { jogkörök } \\
\text { (Hvt. 146. \$) }\end{array}$ & $\begin{array}{c}\text { államháztartási } \\
\text { hitelmúveletek } \\
\text { (Hvt.155.\$) }\end{array}$ & $\begin{array}{c}\text { polgári jogi igaz- } \\
\text { ságszolgáltatás } \\
\text { (Hvt. 159.\$) }\end{array}$ & $\begin{array}{c}\text { határidők elmulasz- } \\
\text { tásából vagy meg nem } \\
\text { tartásából származó } \\
\text { jogkövetkezmények } \\
\text { elhárítása és enyhítése } \\
\text { (Hvt. 162. \$) }\end{array}$ \\
\hline $\begin{array}{c}\text { közig. határozatok } \\
\text { megsemmisítése, } \\
\text { illetve intézkedési } \\
\text { jogkör } \\
\text { (Hvt. 143.\$) }\end{array}$ & $\begin{array}{l}\text { egyesülési jog } \\
\text { korlátozása } \\
\text { (Hvt. 148. \$) }\end{array}$ & $\begin{array}{l}\text { pénzforgalom } \\
\text { szabályozása és } \\
\text { korlátozása } \\
\text { (Hvt. 156. \$) }\end{array}$ & $\begin{array}{l}\text { büntető eljárásjogi } \\
\text { szabályok kiegé- } \\
\text { szítése és módo- } \\
\text { sítása, büntető } \\
\text { eljárásjogi ga- } \\
\text { ranciák (törvényes } \\
\text { bíróhoz való jog) } \\
\text { korlátozása } \\
\text { (Hvt. 160. \$) }\end{array}$ & $\begin{array}{c}\text { közegészségügyi } \\
\text { intézkedések } \\
\text { (Hvt. 163.\$) }\end{array}$ \\
\hline $\begin{array}{c}\text { kormánybiztos } \\
\text { utasítási és } \\
\text { rendelkezési joga } \\
\text { (Hvt. 144. \$) }\end{array}$ & $\begin{array}{l}\text { gyülekezési jog } \\
\text { korlátozása } \\
\text { (Hvt. 149. \$) }\end{array}$ & $\begin{array}{l}\text { közszolgáltatá- } \\
\text { sokkal kapcso- } \\
\text { latos jogkörök } \\
\text { (Hvt.157. \$) }\end{array}$ & $\begin{array}{l}\text { bírók bele- } \\
\text { egyezés nélküli } \\
\text { áthelyezése } \\
\text { (Hvt. 161. §) }\end{array}$ & $\begin{array}{l}\text { temetőkkel kapcso- } \\
\text { latos intézkedések } \\
\text { (Hvt. 164.\$) }\end{array}$ \\
\hline $\begin{array}{c}\text { kormánybiztos } \\
\text { kihágási jogköre } \\
\text { (Hvt. 145. \$) }\end{array}$ & $\begin{array}{c}\text { kiürítés } \\
\text { (Hvt. 147. \$) }\end{array}$ & $\begin{array}{c}\text { nemzeti } \\
\text { hitelintézetek } \\
\text { múködésével } \\
\text { kapcsolatos } \\
\text { jogkörök } \\
\text { (Hvt. 158. } \$ \text { ) }\end{array}$ & & $\begin{array}{c}\text { kötelező biztosítá- } \\
\text { sokkal kapcsolatos } \\
\text { intézkedések } \\
\text { (Hvt. 165. \$) }\end{array}$ \\
\hline
\end{tabular}

93 A szankciórendszerrel kapcsolatban fontos megjegyezni, hogy a Kit. mellett már az 1920-as évektől több külön törvényt is elfogadtak, ezek egymáshoz való viszonyának bemutatása jelen tanulmányban nem lehetséges. Bővebben vö. a Hvt. 1939 tervezetéhez készült részletes indokolással.

94 Hvt. 1939145. \$. 


\begin{tabular}{|c|c|c|c|c|}
\hline $\begin{array}{l}\text { Közigazgatással } \\
\text { kapcsolatos } \\
\text { hatáskörök }\end{array}$ & $\begin{array}{l}\text { Rendészeti } \\
\text { hatáskörölk }\end{array}$ & $\begin{array}{c}\text { Pénzügyi } \\
\text { hatáskörök }\end{array}$ & $\begin{array}{l}\text { Igazságszolgálta- } \\
\text { tással kapcsolatos } \\
\text { hatásköröl }\end{array}$ & $\begin{array}{c}\text { Egyéb kivételes } \\
\text { hatáskörök }\end{array}$ \\
\hline & $\begin{array}{l}\text { kitiltás, fel- } \\
\text { ügyelet, őrizet } \\
\text { (Hvt. 150. \$) }\end{array}$ & & & $\begin{array}{c}\text { érdekképviseleti szer- } \\
\text { vekkel kapcsolatos } \\
\text { jogkörök } \\
\text { (Hvt.166. \$) }\end{array}$ \\
\hline & $\begin{array}{c}\text { sajtóellenőrzés } \\
\text { (Hvt. 151. \$) }\end{array}$ & & & $\begin{array}{l}\text { kereskedelmi társa- } \\
\text { ságokkal és kereske- } \\
\text { dőkkel kapcsolatos } \\
\text { jogkörök (Hvt. 167. \$) }\end{array}$ \\
\hline & $\begin{array}{l}\text { posta-, távíró-, } \\
\text { távbeszélő- } \\
\text { forgalom, } \\
\text { valamint a rádió } \\
\text { ellenőrzése } \\
\text { (Hvt. 152.\$) } \\
\end{array}$ & & & $\begin{array}{l}\text { tanintézetek tanul- } \\
\text { mányi és vizsga- } \\
\text { rendjével, valamint } \\
\text { a képesítő vizsgákkal } \\
\text { kapcsolatos jogkörök } \\
\text { (Hvt. 168. \$) }\end{array}$ \\
\hline & $\begin{array}{c}\text { fegyverekre, } \\
\text { lőszerekre, } \\
\text { robbanószerekre } \\
\text { és más veszélyes } \\
\text { tárgyakra } \\
\text { vonatkozó } \\
\text { korlátozás } \\
\text { (Hvt.153. } \$ \text { ) }\end{array}$ & & & $\begin{array}{c}\text { ipari és gazdasági } \\
\text { foglalkozások gya- } \\
\text { korlásához szükséges } \\
\text { előfeltételektől való } \\
\text { eltérést biztosító } \\
\text { jogkörök } \\
\text { (Hvt. 169. \$) }\end{array}$ \\
\hline & $\begin{array}{l}\text { szeszes italok } \\
\text { kiszolgálásának } \\
\text { korlátozása } \\
\text { (Hvt.154.\$) }\end{array}$ & & & $\begin{array}{c}\text { vagyontárgyak biz- } \\
\text { tonságba helyezésével } \\
\text { kapcsolatos jogkörök } \\
\text { (Hvt. 170. \$) }\end{array}$ \\
\hline
\end{tabular}

2. táblázat

Kivételes hatalom révén szabályozható területek a Hvt. 1939-ben

Forrás: a szerzô saját összeállitása a Hvt. alapján

\subsection{A kivételes hatalom a II. világháború alatt (1939-1945)}

A Hvt. 1939 kivételes hatalomról szóló rendelkezéseire hivatkozással a világháború időszakában folyamatosan készültek rendeletek. Ezek egyik része általában a kivételes hatalom 
igénybevétele érdekében, ${ }^{95}$ másik része pedig az egyes konkrét felhatalmazási szakaszok (142-170. §) alapján került kiadásra. A Hvt. 1939 kivételes hatalomról szóló rendelkezéseire 1945-ben még az Ideiglenes Nemzeti Kormány is hivatkozott, ${ }^{96}$ de ezek a hivatkozások rövid időn belül elmaradtak. ${ }^{97}$ A Hvt. 1939-et majd csak az 1960. évi honvédelmi törvény helyezte hatályon kívül.98

\section{A kivételes hatalom a Rákosi-rendszerben ${ }^{99}(1945-1956)$}

\subsection{Törvényi szabályozás}

Az Ideiglenes Nemzetgyúlés (a továbbiakban: INGY) 1944. december 21-tôl az 1945-ös választást követően létrejött Nemzetgyưlés 1945. november 29-i alakuló üléséig volt a szuverenitás legfőbb letéteményese, ${ }^{100}$ ám ebből eredő jogosítványait csak korlátozottan gyakorolta. ${ }^{101}$ Bár a rendkívüli körülmények között a kivételes hatalomra az új államhatalomnak is égető szüksége lett volna, ezzel kapcsolatos törvénykezésre csak 1946-ban került sor. Miután a születőben lévő államhatalom nem a jogfolytonosságra épült, a Hvt. 1939 felhatalmazására való hivatkozás sem jelentett megoldást. Az egyetlen járható útnak egy sui generis gyakorlat kialakítása túnhetett; végül ezt szentesítették az 1946 és 1949 közötti törvények.

A kivételes hatalom gyakorlása kezdetben azon alapult, hogy „[a]z Ideiglenes Nemzetgyűlés felhatalmazta az Ideiglenes Nemzeti Kormányt az ország ügyeinek vezetésére. Ez a felhatalmazás 1945. szeptemberig szolgált a kormány rendeletalkotó és -kibocsátó tevékeny-

95 Hvt. 1939141. \$, vö.: 8100/1939. ME rendelet (RT 1939. 1266-1267.), 11710/1939. ME rendelet (RT 1939. 2348.), 3650/1940. ME rendelet (RT 1940. 926.), 6090/1940. ME rendelet (RT 1940. 1881.), 9420/1940. ME rendelet (RT 1940. 3344.), 3130/1941. ME rendelet (RT 1941. 1112.), 6320/1941. ME rendelet (RT 1941. 2119.). Lásd még: Vargyai, 1979.

96 Vö.: a közalkalmazottak igazolásáról szóló 15/1945. ME rendelet (MK 1945/1. 3.), a közszolgálatban álló tisztviselők és egyéb alkalmazottak illetményei, továbbá a nyugdíjasok, özvegyek és árvák ellátási díjai tárgyában 800/1945. ME rendelet (MK 1945/22. 1.).

97 1944. december 21-től a szuverenitás kizárólagos letéteményese - így a kivételes hatalom szabályozására jogosult szerv - az Ideiglenes Nemzetgyuulés volt (MK 1945/1. 1.). A jogfolytonosság kérdése nemcsak 1945-ben, hanem már 1918-1920-ban is felmerült. Terjedelmi okok miatt itt csupán említés szintjén hivatkozom Molnár Kálmán munkáira, valamint újonnan megjelent életrajzára (Schweitzer, 2018), továbbá Polner Ödön egyik tanulmányára (Polner, 1931).

98 1960. évi IV. tv. 127. \$.

99 A korszakolásra lásd: Gyarmati, 2011; Palasik, 2000; újabban pedig: Palasik, 2017.

100 A változást az 1945. december 16-án hatályba lépett 1945. évi XI. törvény szentesítette [1. \$ (1) bekezdés].

101 Így például nem alkotott törvényeket. Föglein Gizella megfogalmazásában: az „Ideiglenes Nemzetgyúlés - a háborús körülményekből adódóan, önmagát korlátozva - még nem hozott legmagasabb szintủ jogszabályokat, vagyis törvényeket, csak határozatokat; mivel a budapesti és a dunántúli képviselők, azaz a teljesség híján még »csonka« volt. Így törvényalkotásra tulajdonképpen nem is volt jogosult, pontosabban nem jogosította fel önmagát." (Föglein, 1992, 5. o.). Bővebben az INGY-re: Feitl, 1995. 
ségének alapjául [...] 1945 szeptemberében a kormány újabb felhatalmazást kapott azzal a kiegészítéssel, amely a gyakorlatban már korábban is múködött, hogy a rendelettervezeteket előzetes jóváhagyásra be kell mutatni az INGY Politikai Bizottságának."102

A kivételes hatalomról szóló törvény megalkotására (vagyis a már létező gyakorlat törvénybe foglalására) - az állam gazdasági, pénzügyi és közigazgatási rendjének biztosítása érdekében - az 1946. évi VI. törvénnyel ${ }^{103}$ (a továbbiakban: Kht.) került sor. A Kht.-nek az 1912-es és az 1939-es szabályozással való összevetése révén látható, hogy 1946-ban elsősorban egy ideiglenes, az állami és nemzetgazdasági érdekek megvalósítását lehetővé tevő felhatalmazás készült.

A törvényben meghatározott időbeli és tárgyi hatály csak látszólag szoros, ugyanis a kivételes hatalom időben akár több mint öt hónapig vehető igénybe, és a kibocsátott rendeletekhez csupán a Nemzetgyúlés (a valóságban az INGY, majd az Országgyúlés Politikai Bizottsága) utólagos jóváhagyására volt szükség. ${ }^{104}$

A tárgyi hatály tekintetében a kivételes hatalom alapján csak az államháztartás egyensúlyának helyreállítása érdekében; a Nemzetgyưlés által alkotott törvények kivételével bármely magánjogi, büntetőjogi, közigazgatási és a törvényhozás hatáskörébe tartozó egyéb rendelkezéstől eltérő; a közjogi természetû rendelkezéseket nem érintő szabályozás megalkotására nyílik lehetőség. ${ }^{105}$

A Kht. által biztosított kivételes hatalom a gyakorlatban hasznosnak bizonyult, erre tekintettel lejárta után újabb törvény készült, ${ }^{106}$ amelynek hatályát több alkalommal is - utoljára 1949. december 31-ig - meghosszabbították. ${ }^{107}$

\subsection{Alkotmányi szabályozás}

A Magyar Népköztársaság Alkotmányáról (a továbbiakban: NKA) szóló 1949. évi XX. törvény 1949. augusztus 20 -án lépett hatályba. ${ }^{108}$ Megalkotása az addig de facto monista ala-

102 Palasik, 2000, 36-37. és 47-48. o.

103 A nemzeti kormány részére rendeletek kibocsátására adott felhatalmazásról szóló 1946. évi VI. törvény (a továbbiakban: Kht.).

104 Kht. 1. \$ (2)-(3) bekezdés, illetve 1947. évi XXVI. tv. 2. \$. Ez az ellenőrzési jogkör az 1940-es évek második felében többször változott. Palasik 1944. december és 1945. szeptember között a kormány rendelettervezeteinek előzetes jóváhagyásáról írt (Palasik, 2000, 47-48. o.). A Kht.-ben negyedévenkénti utólagos jóváhagyást kodifikáltak. Az 1947. évi XVI. tv. viszont - a rendeletek elfogadásától számítva - 15 napos határidőt írt elő a kormány számára, hogy a jóváhagyást megkérje.

105 Kht. 1. \$ (1) bekezdés.

106 Lásd: 1946. évi XVI. tv.

107 A Kht.-val (1946. évi VI. tv.) kapcsolatos szabályozás tartalmán azonban az élesedő politikai harcok egyre látványosabb nyomot hagytak. Vö.: 1946. évi XVI. tv., 1946. évi XXVIII. tv., 1947. évi VIII. tv., 1947. évi XXVI. tv., 1948. évi XXIV. tv., 1948. évi LVI. tv., 1949. évi XVII. tv.

108 Az 1949-es alkotmány a Politikai Bizottságot voltaképpen felszámolta, ezáltal a kivételes hatalomról szóló szabályozás a korábban rögzített időtartamnál három hónappal korábban gyakorlatilag hatályát vesztette (lásd bővebben: Mezey, 2003, 254. o.). Vö. még: 1.5.1. pont, valamint 1946. évi XVI. tv. 
pokon álló magyar szabályozást duálissá változtatta, hiszen a törvényi mellett innentől kezdve megjelent az alkotmányi szint is. Kérdéses azonban, hogy a kivételes hatalom szabályozása esetében már 1949-tôl duális szabályozásról beszélhetünk-e, és ha nem, akkor egyáltalán mikor jelenik meg először e jogintézmény az alkotmányban.

\subsubsection{Az első chartális alkotmány}

A kérdés megválaszolásához vissza kell kanyarodni az 1919-es Tanácsköztársasághoz, ugyanis az első magyar írott alkotmány megalkotása e politikai rendszerhez köthető, még akkor is, ha a Magyarországi Szocialista Szövetséges Tanácsköztársaság alkotmánya (a továbbiakban: TKA) ${ }^{109}$ csak rövid ideig maradt hatályban. ${ }^{110}$

A TKA konkrét rendelkezést nem tartalmazott sem a kivételes hatalomról, sem a különleges jogrendről, azonban rendelkezéseinek egybevetése révén kirajzolódnak az ilyen esetben eljárásra jogosult szerv(ek) feladat- és hatáskörei. A TKA alapján a legfőbb hatalmat a Szövetséges Tanácsok Országos Gyúlése gyakorolja. ${ }^{111}$ A TKA szerint ennek hatáskörébe tartozik „minden nagyfontosságú állami ügy”, amelyeket az alkotmány példálódzva, tizennyolc pontban fel is sorol. ${ }^{112}$ E felsorolásból három esetkör ${ }^{113}$ a Szövetséges Tanácsok Országos Gyúlésének kizárólagos hatáskörébe tartozik, de ezek közül csupán a háború és béke kérdésköre kapcsolódhat a kivételes hatalom gyakorlásához is. ${ }^{114} \mathrm{~A}$ többi esetben - amennyiben a Szövetséges Tanácsok Országos Gyúlése nem ülésezik - a Szövetséges Központi Intézőbizottság is eljárhat, ${ }^{115}$ ugyanis ez a szerv ilyenkor „legfőbb intézője az ország ügyeinek: a legfóbb törvényhozói, végrehajtói és bírói hatalmat gyakorolja". ${ }^{116}$ Létezik azonban egy ennél szúkebb körû grémium is, a Kormányzótanács, amelynek tagjait és elnökét a Szövetséges Központi Intézőbizottság választja meg. ${ }^{117}$

A Kormányzótanács alapvető feladata a Tanácsköztársaság ügyeinek - a Szövetséges Tanácsok Országos Gyủlése, valamint a Szövetséges Központi Intézőbizottság utasításainak

109 Lásd: Belügyi Közlöny (a továbbiakban: BK) 1919. 07. 06. 1078-1093.

$110 \mathrm{Az}$ első írott alkotmány az 1919. április 2-án megjelent ideiglenes alkotmány volt (a Forradalmi Kormányzótanács XXVI. sz. rendelete, BK 1919. 04. 06. 705-708.), elemzését lásd: Mezey, 2003, 373-374. o., valamint Bihari, 1979.

111 TKA 15. \$.

112 TKA 16. \$.

113 Ezek a következők: a) az alkotmány megállapítása és megváltoztatása; b) a hadüzenet és békekötés; c) az ország határainak megállapítása. Lásd:TKA 16. \$ harmadik szakasz.

114 Elsősorban oly módon, hogy a békekötés és a hadüzenet időpontja befolyással lehet a kivételes hatalom kezdő és befejező időpontjára, ahogy ez fentebb, a Kit. és Hvt. 1939 kapcsán már részletesen bemutatásra került (1.2. és 1.3. pontok).

115 Vö.: TKA 16. \$ második szakasz és 20. \$.

116 TKA 20. \$ első szakasz. A szövetséges központi intéző bizottság feladat- és hatásköreit lásd még: TKA 20. \$ második szakasz és 21 . \$.

117 TKA 24. \$. 
megfelelő - vezetése. ${ }^{118}$ Ennek során „[á]ltalában megteheti mindazt, ami az állami teendők gyors elintézéséhez szükséges", ${ }^{11}$ azonban rendeleteiről, határozatairól s fontos ügyekben tett intézkedéseirôl haladéktalanul értesíteni ${ }^{120}$ kell a Szövetséges Központi Intézőbizottságot, ${ }^{121}$ amely ezek felett reformatórius jogkörrel rendelkezik, vagyis a Kormányzótanács rendeleteit, határozatait és intézkedéseit megváltoztathatja. ${ }^{122}$ Egyetlen speciális esetben azonban a Kormányzótanács a Szövetséges Központi Intézőbizottság értesítése nélkül is intézkedhet: ez a „rendkívüli sürgősség” esete. ${ }^{123} \mathrm{Ez}$ a megfogalmazás elég tág keretet biztosított (volna) egy olyan helyzetben, amikor a kivételes hatalom gyakorlása általában felmerülhetett.

A TKA fenti rendelkezéseinek összevetése során az első magyar chartális alkotmánynak a kivételes hatalommal kapcsolatos rendelkezéseiről a következő megállapításokat tehetjük:

- a kivételes hatalmat igényló esetek legnagyobb részében a Szövetséges Központi Intézőbizottság lett volna jogosult intézkedni, kivéve, ha a Szövetséges Tanácsok Országos Gyúlése éppen ülésezik;

- egy szúkebb körben azonban, amikor a „rendkívüli sürgősség” megkívánja, a Kormányzótanács a Szövetséges Központi Intézőbizottság bevonása nélkül is eljárhatott volna.

A TKA szövegezése természetesen sok kívánnivalót hagyott maga után, amit valószínúleg már a kodifikátorok is éreztek. A hatásköri összeütközések elkerülése érdekében ezért biztosíthattak szabályozási elsőbbséget a Szövetséges Tanácsok Országos Gyúlésének. ${ }^{124}$ Ez a kivételes hatalom szabályozása tekintetében hosszabb távon az alkotmány módosítása nélkül is megnyitotta volna egy részletes jogszabály elkészítése előtt az utat.

\subsubsection{A kivételes hatalom szabályozása az 1949-es alkotmányban}

Az NKA deklarálja, hogy az Országgyủlés „a Magyar Népköztársaság legfelsőbb államhatalmi szerve”, ${ }^{125}$ amely „gyakorolja a népszuverénitásból folyó összes jogokat, meghatározza a kormányzás szervezetét, irányát és feltételeit" ${ }^{126} \mathrm{E}$ jogkörében az Országgyưlés dönt

118 TKA 26. $\$$.

119 TKA 27. $\$$.

120 A TKA 28. és 30. \$-ának összevetéséből egyértelmúen következik, hogy az értesítésnek előzetesnek kell lennie, és amennyiben a Kormányzótanács mégsem a Szövetséges Központi Intézôbizottság útmutatásai szerint járna el, akkor intézkedései és az általa kibocsátott jogszabályok megváltoztathatók. Vagyis a TKA lényegében egyetértési jogot biztosít a Kormányzótanács tekintetében a Szövetséges Központi Intézőbizottság számára.

121 TKA 28. \$.

122 TKA 29. \$.

123 TKA 30. $\$$ A rendkívüli sürgősség esetkörének kimunkálására nem hagyott időt a történelem, de tipikusan ilyen eset lehet egy természeti katasztrófa vagy hadüzenet nélküli háború esetén a védekező hadműveletek megindítása.

124 TKA 16. \$ második szakasz.

125 NKA 10. \$ (1) bekezdés.

126 NKA 10. $\$(2)$ bekezdés. 
- többek között - a háború és béke kérdésében. ${ }^{127} \mathrm{Az}$ alkotmány egy másik rendelkezése szerint pedig „, [h]áború vagy egyéb rendkívüli körülmények esetén az Országgyűlés megbízatásának meghatározott időre való meghosszabbítását is kimondhatja". ${ }^{128} \mathrm{~A}$ feloszlatott Országgyúlés pedig - háború vagy egyéb rendkívüli körülmények esetén - ismét összehívható; az összehívásra a Népköztársaság Elnöki Tanácsa jogosult. ${ }^{129}$

A Népköztársaság Elnöki Tanácsa (a továbbiakban: NET) az NKA szovjet alkotmányból átvett újítása volt, egyfajta kollektív államfó, amelynek legfontosabb feladata az alig ülésező Országgyúlés helyettesítése volt. ${ }^{130}$ Hatáskörével kapcsolatban két jogszabályhelyet kell itt megemlíteni. A NET egyrészt eljárhat mindazon ügyekben, amelyet törvény a hatáskörébe utal, ${ }^{131}$ másrészt amikor az Országgyuulés nem ülésezik, „jogkörét a Népköztársaság Elnöki Tanácsa gyakorolja; az Alkotmányt azonban nem változtathatja meg”. ${ }^{132}$ A minisztertanács az új alkotmányban egyszerú végrehajtó szervvé vált,, ${ }^{133}$ és mint ilyen, a kivételes hatalom gyakorlása szempontjából nem jött számításba.

Az NKA alapján tehát a kivételes hatalom gyakorlója az Országgyúlés és a NET lehetett, bár láthattuk, hogy egyértelmú szabályozás helyett a jogalkotó megelégedett csupán az „egyéb rendkívüli körülmények” fordulat elhelyezésével - amelybe természetesen a kivételes hatalom gyakorlását kiváltó események is beleérthetôk. Nehezebb azonban az ilyen esetben eljárásra jogosult szerv egyértelmú meghatározása, ugyanis az NKA látszólag csupán az alkotmánymódosítást tartja fenn kizárólagos hatáskörként az Országgyúlés részére, valójában azonban az NKA 18. \$-ban az Országgyúlés megbízásának saját hatáskörben történő meghosszabbítása arra utal, hogy a „háború és egyéb rendkívüli körülmények” esetköre fontossága miatt elsősorban az Országgyưlés intézkedését igényelné. Miután az egyéb rendkívüli körülmények a NET hatáskörei között nem kerültek tételes felsorolásra, és a kérdést külön törvényben sem rendezték, mind az Országgyưlés, mind a NET elsőbbsége mellett több érvet is fel lehetett sorakoztatni, ami - ha nem kirakatalkotmányról lett volna szó - egy kritikus helyzetben könnyen koherenciazavart idézhetett volna eló.

A jogalkotó maga is érzékelte a szöveg hiányosságait, de a kivételes hatalom ügyében a szükséges alkotmánymódosítás már csak a Kádár-rendszerben készült el (3.2. pont).

127 NKA 10. $\$(3)$ bekezdés $g$ ) pont.

128 NKA 18. $\$(2)$ bekezdés.

129 NKA 18. $\$(3)$ bekezdés.

130 Lásd bővebben: Mezey, 2003, 396-398. o.

131 NKA 20. \$ (1) $k$ ) pont.

132 NKA 20. $\$$ (4) bekezdés.

133 NKA 22-28. \$. 


\subsubsection{A kivételes hatalom szabályozásának hasonlóságai és különbségei} az 1919-es és az 1949-es alkotmányokban

Bár az 1949-es alkotmány már preambulumában visszautalt az 1919-es Tanácsköztársaságra, hidat létesítve ezáltal a két jogi rezsim között is, érdemes megvizsgálnunk, hogy vajon a kivételes hatalom szabályozásában voltak-e hasonlóságok a két alkotmány, a TKA és az NKA között.

Ahogy az 1919. és 1949. évi történelmi helyzet, úgy a két alkotmány keletkezési körülményei is eltérnek egymástól. Bár a TKA-t a hatályos szovjet alkotmány ${ }^{134}$ ismeretében szövegezték, a szövegszerú egyezések ellenére is számos egyedi jellegzetességgel bírt. ${ }^{135}$ Az NKA viszont „jórészt az 1936-os szovjet alkotmány mintájára készült. A szerkesztőknek csak [...] az eltéréseket kellett indokolniuk." ${ }^{136}$

Bár a kivételes hatalomra mindkét alkotmány szövegében csupán utalások találhatók, amelyek megnehezítik a jogalkotói szándék kiderítését, az egyértelmúen megállapítható, hogy a kivételes hatalom gyakorlására jogosultak körében jelentős eltérések vannak. A TKA alapján - mint láthattuk - a Kormányzótanácsnak az esetek nagy részében lehetősége nyílik, hogy rendkívüli körülmények között eljárhasson. Az NKA szerint viszont a Minisztertanácsnak semmilyen ehhez hasonló jogosítványa nem maradt. A kormány (Minisztertanács) jogosítványainak eltúnése, amely egyébként szöges ellentétben állt a magyar jogfejlődési tendenciákkal, ${ }^{137}$ egyértelmúen a NET szovjet alkotmányból a magyar jogrendszerbe való beültetésével magyarázható. Míg az 1919-es szabályozás alapján elképzelhető volt némi szervezeti összjáték egy rendkívüli állapot kezelése esetén, addig 1949-ben a jogalkotói cél egyértelmúen egy, az államigazgatás teljes vertikumát uraló és azt szabályozni képes - egyébként az állampárttal összefonódó - intézmény megalkotása volt. Ennek megfelelően az NKA kapcsán fentebb feltett kérdések többsége is egyértelmúen megválaszolható, hiszen az 1949-es alkotmány szerkezetéből egyértelmúen a NET-nek a kivételes hatalommal való felruházása következett volna, viszont e kérdés egyértelmú rendezése az NKA szövegében elmaradt. ${ }^{138}$

$134 \mathrm{Az}$ 1918. július 10-i alkotmány szövegét lásd: http://constitution.garant.ru/science-work/modern/3988990/ chapter/b89690251be5277812a78962f6302560 (Letöltve: 2020. december 10.).

135 Lásd bővebben: Bihari, 1979, 200-202. o.

136 Mezey, 2003, 388. o.

137 Vö. jelen könyvfejezet 1.2. és 1.3.3. pontjait.

138 A szabályozás hiányos volta már a kortársaknak is feltûnt, lásd például Ádám Antalnak a NET hatásköreiről szóló kétrészes tanulmányát. Ádám, 1967a; Ádám, 1967b. 


\section{A kivételes hatalom szabályozása a Kádár-rendszerben $(1956-1989)^{139}$}

\subsection{Törvényi szabályozás}

\subsubsection{Az 1960-as honvédelmi törvény}

Az 1956-os forradalom és szabadságharc után még néhány évnek kellett eltelnie, mire egy új honvédelmi törvény tervezete az Országgyûlés elé került. Az 1960-as honvédelmi törvény ${ }^{140}$ megalkotásának indoka kettős volt: egyrészt a haderőfejlesztést kívánta elősegíteni, másrészt a hatályos joganyagnak az NKA-val való harmonizációját kívánta megvalósítani egy hosszabb távú jogalkotási program részeként. ${ }^{141}$ Ez utóbbi cél: a jogharmonizáció nem volt mentes az ideológiai töltettől, hiszen a szocialista Magyarországon pontosan a kivételes hatalom és annak a Hvt. 1939-ben a II. világháború kezdetén kiteljesedő szabályozása jelképezte „az akkori uralkodó osztálynak a totális fasiszta diktatúrára, a rablóháborúban való részvételre és nem utolsósorban a munkásmozgalom, illetôleg az antifasiszta mozgalom teljes megsemmisítésére irányuló törekvését". ${ }^{142}$

A Hvt. 1939 kivételes hatalomról szóló része viszont egy több évtizedes jogfejlesztés eredményeként került 1939-ben kodifikálásra. Az új hatalom ezzel a „kodifikációs bravúrral” minden ideológiai viszolygása ellenére is élni akart, ${ }^{143}$ ezért a korábbi szabályozás több elemét is átemelte a Hvt. 1960-ba. Maga a kivételes hatalom jogi rezsimje Rendkívüli intézke-

139 A kérdésre lásd még: Szentpáli-Gavallér, 2020. Az 1956-os forradalom időszakának a téma szempontjából releváns, jogtörténeti szempontú vizsgálatát terjedelmi okok miatt mellőztük.

140 A honvédelemről szóló 1960. évi IV. törvény (a továbbiakban: Hvt. 1960).

141 Czinege Lajos honvédelmi miniszter expozéjában külön ki is emelte, hogy „Alkotmányunk keletkezése óta, a benne lefektetett alapelveknek megfelelően - a szocializmus építése során - gyökeres átalakuláson ment át és mélyrehatóan megváltozott államunk egész rendje, gazdasági, társadalmi és politikai szerkezete, kialakult tehát az új alap, amely szükségszerúen maga után vonja a felépítmény megváltoztatását is. Az új jogi felépítmény ennek a fejlődésnek a menetében nem egy csapásra, hanem a jogi szabályozás különböző területeinek fokozatos átalakítását célzó új szocialista jellegú törvények megalkotása útján jön létre. Az egységes és teljes szocialista jogrendszer kiépítésének jegyében születtek meg a korábbi években az alkotmány elvi tételeit részletes jogi szabályozásban realizáló legfontosabb törvényeink [...] Készülő́ben van más fontos jogterületek újszerủ szabályozása is [...] A szocializmus építése során kialakult új gazdasági és társadalmi viszonyok így érlelték törvényhozásunk időszerű feladatával az alkotmányos honvédelmi kötelezettség tartalmának és a honvédelmi igazgatás rendjének szabályozásáról szóló új honvédelmi törvény megalkotását is." [Országgyúlési Napló (a továbbiakban: OGYN) 1960. 12. O1-jei ülésnap, 758. o.].

142 Vö.: általános indokolás az 1960. évi IV. törvény tervezetéhez. Hasonlóan nyilatkozott egyébként a törvényjavaslat elfogadásakor az előterjesztő honvédelmi miniszter is (OGYN 1960. 12. 01-jei ülésnap, 759. o).

143 Ez egyébként az 1960. évi IV. törvény tervezetéhez készített indokolásból is kiderül, vö.: általános indokolás és részletes indokolás a XXI. fejezethez. 
dések háború idején cím alatt került kodifikálásra. ${ }^{144} \mathrm{Nem}$ külön törvényben, mint ez egyébként az NKA 10. \$ (3) bekezdés a) pontja, valamint a 20 . $\$$ (1) bekezdés $k$ ) pontja alapján kézenfekvő lett volna, hanem - az 1939-es szabályozás szellemének megfelelően - újra a honvédelmi törvényben.

A Hvt. 1960 XXI. fejezete lényegében részben az 1939-es szabályozás egyes elemeinek átvételével, ${ }^{145}$ részben azok átfogalmazásával ${ }^{146}$ és kiegészítésével készült. Az egyik leglátványosabb jogalkotói döntésnek a kormánybiztos intézményének megőrzése számított, még akkor is, ha múködése kizárólag háború idejére korlátozódott; ${ }^{147}$ és még ekkor sem vonta „maga után az államhatalom helyi szervei, illetőleg a tanácsi végrehajtó bizottságok múködésének még csak ideiglenes szünetelését sem". ${ }^{148}$

Pontosító jellegû́ volt, hogy a Hvt. 1939 által következetesen használt kártérítés helyére a Hvt. 1960-ban mindenütt kártalanítás lépett, ugyanis az előterjesztő a szóhasználattal azt kívánta kifejezésre juttatni, hogy „nem jogellenes, hanem jogos, törvényen alapuló intézkedésekből eredő hátrányról van szó [...]” ${ }^{149}$

A Hvt. 1960 XXI. fejezetében a leglényegesebb újítás a Hvt. 1939-hez képest a személyi tulajdonban álló gépjármúvek használatának honvédelmi célból történő megtiltása vagy korlátozása mint önálló pont beiktatása volt - ezt azonban elsősorban a gépjármúvek rohamos elterjedése indokolhatta. ${ }^{150}$

Végül, ha a fentiekből nem vált volna nyilvánvalóvá a Hvt. 1939 és a Hvt. 1960 közötti erős átfedés, akkor érdemes egy pillantást vetni a Hvt. 1960 XXI. fejezetének végén [123. \$ (1) bekezdés] elhelyezett felhatalmazásra, amely szerint „,[a] jelen fejezetben meghatározott rendkívüli intézkedéseket a Minisztertanács rendeli el". Valóban, ez volt a Hvt. 1939, valamint az 1912-es Kit. alapkoncepciója is, viszont a Minisztertanács kivételes hatalommal való fel-

144 A Hvt. 1960 által használt „rendkívüli intézkedések” fogalom, ha nem is illeszkedett tökéletesen az NKA által alkalmazott „rendkívüli körülmények” fogalmához, de nyilvánvalóvá tette a két szabályozás kapcsolatát.

145 Érdemes összevetni a Hvt. 1960 XXI. fejezetének szakaszait (115-122. \$) a Hvt. 1939 rendelkezéseivel, és az átfedések azonnal láthatóvá válnak. Nézzük meg a Hvt. 1960 paragrafusait úgy, hogy mögéjük helyezzük (zárójelben) a korábbi törvény, a Hvt. 1939 kapcsolódó szakaszait: 115. $\$$ (1) bekezdés - (140. \$), 115. \$ (2) bekezdés - (140. \$), 116. $\$-(149 . \$), 117 . \$-[151 . \$(1)-(4)$ bekezdés], 118. $\$(1)-(2)$ bekezdés - [147. $\$(1),(3)$ bekezdés], 119. $\$$ (1)-(2) bekezdés - [170. $\$(1),(3)$ bekezdés], 120. $\$-[163 . \$(1)-(3)$ bekezdés], 121. $\$(1),(3)$ bekezdés $-[170 . \$(1)$, (3) bekezdés], 121. $\$(2)-(3)$ bekezdés - $(152 . \$), 122 . \$(1)$ bekezdés - [142. $\$ d)$ pont], 122. $\$(2)$ bekezdés $-[142 . \$$ e) pont].

146 Lásd például a Hvt. 1960117. \$-át, amely a Hvt. 1939151. \$ (1)-(4) bekezdéseinek összevonásával és pontatlanabb megszövegezésével készült. A Hvt. 1960115. \$ (1)-(2) bekezdése látszólag jogfejlesztést tartalmaz, ha csak a Hvt. 1939-cel vetjük össze, de ha vizsgálódásunkba a Kit.-et is bevonjuk, egyértelmúvé válik, hogy egy precízebb normaszöveget sikerült kevésbé szabatos formába átfogalmazni. Pozitív ellenpélda is akadt azonban, lásd például: Hvt. 1960120 . \$, ahol a normaszöveg egyszerúsödött, viszont a rendelkezés céljában lényegi változás nem történt.

147 Vö.: Hvt. 1960122. \$ (1) bekezdés.

148 Vö.: Indokolás az 1960. évi IV. törvény tervezetéhez, részletes indokolás a 114-123. \$-hoz.

149 Vö.: Indokolás az 1960. évi IV. törvény tervezetéhez, részletes indokolás a 114-123. \$-hoz.

150 Ugyanis a Hvt. 1939170. \$-ának generális felhatalmazása alá egyébként a személyi tulajdonban álló gépjármúvek is befértek volna. 
ruházása - ahogy fentebb láthattuk (2.2.2. pont) - éles ellentétben állt az NKA koncepciójával, ahol a kormány puszta végrehajtó szerv, és a hatáskörök szinte kizárólagos birtokosa a NET volt. Az a NET, amely a Hvt. 1960 többi részében egyébként további felhatalmazásokat kapott, köztük olyanokat is, amelyek a Hvt. 1939-ben még a Minisztertanácsot illették. ${ }^{151}$ A Minisztertanács és a NET hatásköreinek Hvt. 1960-ban történt összemosása tehát éppen a jogalkotó egyik fô célkitúzését, az NKA-nak megfelelő joganyag elkészítését hiúsította meg (ráadásul egy jogállamban súlyos koherenciazavarhoz is vezethetett volna egy rendkívüli állapot bevezetése esetén). ${ }^{152}$

\subsubsection{Az 1976-os honvédelmi törvény}

A honvédelemról szóló 1976. évi I. törvény (a továbbiakban: Hvt. 1976) preambuluma szerint a törvény megalkotására elsősorban a védelmi képesség növelése, a honvédelem szervezetrendszerének szabályozása, illetve a honvédelmi kötelezettséget teljesíto állampolgárok jogainak és kötelezettségeinek rögzítése miatt volt szükség. ${ }^{153}$

A Hvt. 1976 szövege és a törvényjavaslat indokolása egyaránt terjengős, és a Hvt. 1960 ellentmondásainak kiküszöbölése helyett a többszintûvé váló szabályozással ${ }^{154}$ csupán állandósította az értelmezési nehézségeket. ${ }^{155}$

A kivételes hatalom szabályozása tekintetében a Hvt. 1976-nak voltak előremutató kezdeményezései, mint például a rendkívüli helyzet esetköreinek elkülönítése, az egyes helyzetekhez feladat- és hatáskörök hozzárendelése vagy a Hvt. 1939 kivételes hatalomról szóló feladat- és hatásköri kataszterének újraszabályozása. Ezek miatt még akkor is sikeres kodifikációs kísérletről beszélhetünk, ha az újszerủ szabályozási koncepciót nem sikerült végigvezetni az egész törvényen, és a kivételes hatalomról szóló Negyedik rész szövegezése számos helyen nehézkes és ellentmondásokkal terhelt. ${ }^{156}$

151 Vö.: Hvt. 1939141. \$ (7) és Hvt. 1960 8. \$ (3) bekezdés. Ami 1939-ben minisztertanácsi hatáskör, ott 1960-ban már a NET járhat el!

152 Illetve hiúsíthatta volna meg, ha a szocialista jogrendben a jogszabályi hierarchia vagy a normaszövegek tartalma következetesen érvényesült volna. A korabeli jogszabályok relatív voltának rekonstruálhatóságára lásd: Germuska, 2011.

153 Lásd még: Indokolás az 1976. évi I. törvény tervezetéhez, általános indokolás.

154 Alkotmány, törvény, végrehajtási rendeletek (MT rendelet és HM rendelet is), törvényjavaslat indokolása.

155 Vagyis a Hvt. 1976 magán viselte a korszak valamennyi kodifikációs jellegzetességét. A „szocialista jogrendszerben a jogállamiság követelményével szemben az úgynevezett többszintú szabályozás vált uralkodóvá. [...] Az alacsony szintú jogszabályok tekintetében a jogi túlszabályozás vált általánossá" - foglalta össze az egyik jogtörténeti tankönyv (Mezey, 2003, 395. o.).

156 İgy például a Hvt. 1976 54. \$ (1) bekezdése szerint „[h]áború idején a szükséghez képest el lehet rendelni a XVIII. és XIX. fejezetben meghatározott, valamint egyéb rendkívüli intézkedéseket". Ez utóbbi fogalom részben valószínúleg utalás a XIX. fejezet címére (a gazdálkodást érintő és egyéb rendkívüli intézkedések), amit azonban az idézett törvényhely külön is megemlített. Az „egyéb rendkívüli intézkedések” így voltaképpen definíció és rendszertani elhelyezkedés nélkül maradtak, ami egy intézkedést igénylő helyzetben akár súlyos hibákat is előidézhet(ett volna). Súlyosabb jogalkotási problémára utal, hogy ez a rendelkezés a Hvt. 1976 1994es hatályon kívül helyezéséig változatlanul fennmaradt. 
Ennél nagyobb probléma azonban, hogy a Hvt. 1976 - miközben a Hvt. 1939-ből átemelte és újraszabályozta a Honvédelmi Tanács intézményét ${ }^{157}$ - a szabályozás szintjén ${ }^{158}$ (elméletileg) lehetővé tette, hogy a kivételes hatalom gyakorlása kikerüljön a polgári hatóságok kezéből. ${ }^{159}$

Terjedelmi okok miatt itt csupán röviden vehetjük sorra a Hvt. 1976 kivételes hatalommal kapcsolatos szabályait:

- A Hvt. 1976 elődjéhez hasonlóan jelentős mértékben támaszkodott a Hvt. 1939 szabályozására, azonban a releváns szabályok egy részét a Rendkivüli intézkedések elnevezésû́ Negyedik részen kívül helyezte el (XIV-XVI. fejezetek). Maga a Negyedik rész három fejezetből (XVII-XIX. fejezetek) áll, de egyes, a kivételes hatalom gyakorlásához kapcsolódó rendelkezések (például honvédelmi szabálysértések és honvédelmi kötelezettségszegés miatt kiszabott szankciók) a záró rendelkezéseket tartalmazó Ötödik részben találhatók.

— A Hvt. 1976 egyik fó újítása a Hvt. 1960-hoz képest a decentralizáció volt. Míg a Hvt. 1960 koncepciója szerint a kivételes hatalom birtokosa elsősorban a Minisztertanács (kormány) volt, a Hvt. 1976 szerint viszont a rendkívüli intézkedéseket a NET vagy a Minisztertanács (kormány), illetve a Minisztertanács (kormány) felhatalmazása alapján az illetékes miniszter vagy a megyei honvédelmi bizottság, valamint múveleti területen a katonai parancsnok is elrendelhette. ${ }^{160} \mathrm{~A}$ kormánybiztos intézménye eltûnt a rendszerből.

- A Hvt. 1976 - felismerve, hogy kivételes hatalmat igénylő helyzetek nem csak háború esetén állhatnak elő - megkísérelte a rendkívüli helyzetek csoportosítását. Négy esetkört különített el: háború, ${ }^{161}$ az állam biztonságát fenyegető veszély; ${ }^{162}$ a közrend

157 A Honvédelmi Tanács 1972 óta szerepelt az alkotmányban. A Hvt. 1976 egyik feladata az alkotmányi szabályozással való összhang megteremtése volt, amint ezt Czinege Lajos honvédelmi miniszter a törvényjavaslat vitája során hangsúlyozta is: „Az alkotmány rendelkezéseivel összhangban rögzíti az Országgyúlésnek és az Elnöki Tanácsnak az ország védelmével összefüggő jogkörét. Külön említést érdemel az a rendelkezés, amely a rendkívüli hatáskörrel felruházott Honvédelmi Tanács létrehozásáról és feladatairól szól. Az alkotmány szerint az Elnöki Tanács rendkívüli viszonyok esetén Honvédelmi Tanácsot hozhat létre. Jogállásának és feladatai meghatározásának törvényi szabályozása - a felkészülés érdekében - azonban már most indokolt, szükséges" (OGYN 1976. 03. 18-i ülésnap, 406. o.).

158 Vö.: a Hvt. 1976 9. \$ (3) és (4) bekezdését, amely szerint „[a]z Elnöki Tanács állapítja meg a Honvédelmi Tanács összetételét, választja meg elnökét, titkárát és tagjait”, illetve „[a] Honvédelmi Tanács elnöke a fegyveres erők és fegyveres testületek főparancsnoka". Ez a rendelkezés egészen 1989 decemberéig hatályban maradt.

159 A normaszöveg és a törvényjavaslat indokolásának összevetéséből az tủnik legvalószínúbbnek, hogy a megfogalmazással a jogalkotó a lehető legtágabb hatáskört kívánta biztosítani a NET számára a rendkívüli helyzetben történő eljáráshoz (vagyis a látszattal ellentétben itt egy alapvetően pozitív előjelû́ kodifikációról van szó). A kivételes hatalom polgári hatóságok alá rendelése - kvázi alapelvként - 1912 és 1976 között politikai rendszertől függetlenül valamennyi szabályozásban szerepelt.

160 Hvt. 197654 . $\$(3)-(5)$ bekezdés.

161 Hvt. 19764 . $\$(1)$ bekezdés.

162 Hvt. 1976 54. \$ (2) bekezdés, azonban a törvény elején [Hvt. 1976 4. \$ (2) bekezdés] a fogalmat a jogalkotó az állam biztonságát súlyosan fenyegető veszélyként kodifikálta. 
és közbiztonság védelme; ${ }^{163}$ elemi csapás elhárítása, illetőleg következményeinek csökkentés ${ }^{164}$ érdekében elrendelt rendkívüli intézkedések, de ezek dogmatikai hátterének kidolgozásával adós maradt. ${ }^{165}$

- Maguk a rendkívüli intézkedések többségükben azonosak a Hvt. 1939-ben és a Hvt. 1960-ban szereplőkkel. Az új rendelkezéseket részben a technikai fejlődés, ${ }^{166}$ részben a szocialista államrendszer kiépülése ${ }^{167}$ indokolta, de átfogó rendszerezésük a törvény 1994-es hatályon kívül helyezéséig sem történt meg.

\subsection{Alkotmányi szabályozás}

A kivételes hatalom alkotmányi szabályozásának keretei egészen 1972-ig változatlanok maradtak az NKA-ban. A korszak legfontosabb változását, a Honvédelmi Tanács (a továbbiakban:HT) kodifikációját az 1949. évi XX. törvény módosításáról és a Magyar Népköztársaság Alkotmányának egységes szövegéről szóló 1972. évi I. törvény valósította meg. ${ }^{168}$ A HT mint jogintézmény valószínűleg a Hvt. 1939-ből került át az NKA-ba, ${ }^{169}$ de a jogalkotó ezzel egyidejủleg az alkotmányi szabályozáshoz kapcsolódó részletszabályok megalkotását - a Hvt. 1960 módosításával - nem végezte el. Erre csupán négy évvel később, a Hvt. 1976 elfogadásával került sor. E törvény megalkotásával ugyanis a jogalkotó egyik kiemelt célja az NKA és a Hvt. 1960 összhangjának megteremtése volt, többek között a HT hatásköreire vonatkozóan. ${ }^{170}$

163 Hvt. 1976 54. \$ (2) bekezdés.

164 Hvt. 1976 54. $\$(2)$ bekezdés.

165 Az előterjesztő erre csupán a Hvt. 1976 javaslatának indokolása során tett egy halvány kísérletet (részletes indokolás az 1-5. \$-hoz, valamint az 55-56. \$-hoz). A dogmatikai háttér hiánya különösen annak fényében szembetűnő, hogy az időleges munkakötelezettségről szóló 1967. évi 27. tvr. már a mai katasztrófavédelmi szabályozás alapjait fektette le, amikor „elemi csapás, valamint az ország érdekét fenyegető egyéb veszély elhárítása érdekében" lehetővé tette az állampolgárok békeidőben történő ideiglenes munkára kötelezését. Lásd még: az 1967. évi 27. tvr. végrehajtásáról szóló 50/1970. (XII. 20.) Kormányrendeletet is. A jogintézmény szabályozási előzményei egyébként a Hvt. 1939-re vezetők vissza (vö.: Hvt. 1939 92. \$). Az elméleti háttérre lásd: Székely, 1964; Czank, 1978.

166 Lásd: radioaktív, nukleáris, sugárzó anyagokra és a músorvevő készülékekre vonatkozó szabályok [Hvt. 1976. 55. $\$(6)$ bekezdés].

167 Vö.: tervgazdálkodás bevezetése [Hvt. 1976 56. \$ (2) bekezdés], szövetkezetek közvetlen állami felügyelet alá vonása [Hvt. 1976 56. \$ (3) bekezdés], múvelődési intézmények múködésének korlátozása vagy beszüntetése [Hvt. 1976 56. $\$(7)$ bekezdés].

168 A törvényjavaslat vitájakor elhangzott, hogy az alkotmánymódosítás egyik célja a Magyar Népköztársaság biztonságának növelése. Ezt „szolgálja az az új rendelkezés, amely szerint háború, vagy az állam biztonságát súlyosan fenyegető veszély esetére az Elnöki Tanács rendkívüli hatáskörrel felruházott honvédelmi tanácsot hozhat létre, továbbá az állam biztonságát súlyosan fenyegető veszélyt, illetve annak megszüntetését az Elnöki Tanács állapítja meg és hirdeti ki" (Kállai Gyula expozéja, OGYN 1972. 04. 19-i ülésnap, 560. o.).

169 Vö.: Hvt. 1939 3. \$ (Legfelső Honvédelmi Tanács). Ugyanakkor meg kell jegyezni, hogy a látszólagos szabályozási hasonlóság nem jelent intézményi vagy tartalmi azonosságot, mint ez Kelemen Roland tanulmányából egyértelmúen kiderül (Kelemen, 2018).

170 Vö.: Czinege Lajos honvédelmi miniszter expozéja (OGYN 1976. 03. 18-i ülésnap, 406. o.). 


\subsection{A kivételes hatalom jogi rezsimjének változásai a 20. század másodikfelében}

Az 1944 és 1994 közötti fél évszázad során több, különböző mélységû́ rendszerváltás zajlott le Magyarországon. Az 1944 és 1989 közötti politikai rendszerek egyik legfontosabb közös jellemzője az állami szuverenitás korlátozott voltában jelölhetô meg. Az ideológiai eltérések mellett valószínúleg ez a korlátozott szuverenitás az oka annak, hogy a kivételes hatalom szabályozása és a jogintézmény használata az 1912-1944 közötti időszakhoz képest háttérbe szorult.

Bár a korszakban több honvédelmi törvény is készült, ezek egyaránt az 1944 előtti szabályozásból merítkeztek, ahogy 1956 után az alkotmány is. Maga a jogintézmény kodifikációja nem élvezett elsőbbséget a honvédelmi jogharmonizáció során, sőt - mint láthattuk - még a különböző, alkotmányi és törvényi szintû szabályozások összhangjának megteremtésére sem törekedtek. A kivételes hatalom fogalmához a szocialista időszakban egyértelmúen negatív politikai jelentéstartalom társult, de pusztán az ideológiai megfontolások nem akadályozták meg, hogy a jogalkotó rendszeresen visszanyúljon az 1939-es szabályokhoz. A jogintézményen a szovjet megszállás időszakában (1944-1989 között) tulajdonképpen csak a legfontosabb technikai jellegú jogfejlesztéseket végezték el, ${ }^{171}$ de az átfogó, koncepcionális újrakodifikálás mindvégig elmaradt. A két jelentős kivétel közül negatív előjellel említhető a HT katonai vezetés alá rendelése, ami egyértelmú szakítást jelentett a magyar jogi hagyományokkal, de még a HT esetében sem beszélhetünk világos koncepció kialakításáról. Az egyetlen jelentős, pozitív jellegú kivétel a jogalkotó azon felismeréséből ered, hogy az alapvetően háborús célokra kifejlesztett jogi rezsim más kivételes esetekben is használható. A kivételes hatalmat igénylő helyzetek kategorizálására a Hvt. 1976-ban került sor, de egységes koncepciót ebben az esetben sem sikerült felmutatni.

Mindezek ismeretében a kivételes hatalommal kapcsolatos szabályozás 20. századi története két nagy szakaszra bontható. ${ }^{172}$ 1912-1944 között, a világháborús erőfeszítések, majd a függetlenné váló magyar állam újjászervezése érdekében végzett küzdelem időszakában egy dinamikus szabályozási szakasz látható, amelynek kodifikációs csúcsteljesítménye a Hvt. 1939 kivételes hatalomról szóló része. Az 1944-1989 közötti időszak ezzel szemben egy statikus, minimális jogfejlesztéssel járó időszak, amelyben a jogalkotó - bár felismeri a szabályozási igényt - minimális érdeklódést mutat egy saját koncepció kidolgozása iránt, inkább megelégszik a Hvt. 1939 vonatkozó szabályozásának újrahasznosításával.

171 Lásd például: a nukleáris energia fogalmának megjelenése, személygépkocsi kisajátításának szabályozása.

172 Korszakolás szempontjából a századokat a szigorú kronológiai kötöttségek helyett didaktikai okokból a magyar szempontból kiemelkedő korszakhatárokhoz kötve értelmezem, így jelen írásban a „rövid huszadik század" történettudományban gyakran használt fogalmára (1914-1989) támaszkodtam (vö. például: Lukacs, 2020, 5-14. o.), mert ez a kivételes hatalom kodifikációjának tárgyalását is megkönnyíti. 


\section{A kivételes hatalom szabályozása a rendszerváltást követő évtizedekben (1989-2010)}

\subsection{Alkotmányi szabályozás}

Az 1989-es „törvényes forradalom”173 során politikai alkuk révén és jogi eszközök segítségével rövid idő alatt lezajlott a piacgazdaságba történő átmenet. A rendszerváltás egyik fontos aktusa, az alkotmányrevízió megtörténte után az alsóbb szintű joganyag újrakodifikálása több évig elhúzódott.

A kivételes hatalom esetében az alkotmányi szabályok megváltoztatása az alkotmány módosításáról szóló 1989. évi XXXI. törvénnyel 1989. október 23-án megtörtént. Az alkotmányrevízió a vizsgált jogintézmény tekintetében minőségi változással járt. ${ }^{174} \mathrm{~A}$ módosított alkotmány (a továbbiakban: MKA) elvégezte a kivételes hatalmat igénylő esetkörök Hvt. 1976 által félbehagyott tipizálását. Az MKA - a jogforrási hierarchia legfelső szintjén - három esetkört konstituált: ${ }^{175}$ hadiállapot, rendkívüli állapot, szükségállapot. ${ }^{176} \mathrm{Ez}$ a csoport 1993-ban a váratlan támadás, ${ }^{177}$ 2004-ben a megelőző védelmi helyzet ${ }^{178}$ esetköreivel bővült. ${ }^{179} \mathrm{~A}$ jogalkotó egyúttal - valószínúleg érzékelve a túl tág megfogalmazásban rejlő veszélyeket - újrakodifikálta a Honvédelmi Tanács intézményét is, és a HT elnökévé civil döntéshozót, a köztársasági elnököt tette meg. ${ }^{180}$ Ugyancsak jogalkotói döntés nyomán a részletszabályok kidolgozása törvényi - illetve kisebb részben rendeleti - szinten történt meg a rendszerváltás utáni években.

Itt kell továbbá megemlíteni, ${ }^{181}$ hogy 2004-ben a hadkötelezettség katonai szolgálati kötelezettségének megszüntetése kapcsán az alkotmányban rögzítették a rendkívüli állapot idején vagy megelőző védelmi helyzetben a hadkötelezettséggel, valamint a rendkívüli állapot idején a honvédelmi munkakötelezettséggel kapcsolatos szabályokat. ${ }^{182}$

173 A Deák István által az 1848-as forradalomra használt kifejezés 1989-re is használhatónak tûnik, mert ahogy ott az áprilisi törvényekhez (1848. 04. 11.), itt egy teljes alkotmányrevízióhoz (1989. 10. 23.) mint szimbolikus eseményhez kapcsolható a rendszerváltás megindulása (amely azonban, 1848-hoz hasonlóan, inkább egy többlépcsős, hosszabb folyamatként képzelhető el). A fogalom használatát lásd bővebben: Deák, 1983.

174 A kivételes hatalom gyakorlását lehetővé tévő esetkörök tartalma, alkalmazásának feltételei az 1989. évi XXXI. törvény, valamint a törvényjavaslat miniszteri indokolása alapján egyértelmúen elkülöníthetők.

175 Lásd még: Petrétei, 2006.

176 MKA 19/A-19/D. \$.

177 MKA 19/E. \$, beiktatta az Alkotmány módosításáról szóló 1993. évi CVII. törvény, hatályos 1994. 01. 01-től.

178 MKA 19. \$ (3) bekezdés $n$ ) pontja, beiktatta az Alkotmány módosításáról szóló 2004. évi CIV. törvény, hatályos 2005. 01. 01-tól.

179 Till, 2019.

180 MKA 19/B \$ (2) bekezdés. Ezzel egyidejúleg a HT korábbi, törvényi szintú szabályozása [Hvt. 1976 9. \$ (2)-(4) bekezdés] hatályát veszítette.

181 Lásd még: Szentpáli-Gavallér, 2020, 10. o.; Farkas-Kádár, 2016.

182 A Magyar Köztársaság Alkotmányáról szóló 1949. évi XX. törvény módosításáról szóló 2004. évi CIV. törvény, hatályos: 2005. 01. 01-jétől. 


\subsection{Törvényi szabályozás}

A rendszerváltást követően a Hvt. 1976 még évekig hatályban maradt, és csak 1994 elejétól váltotta le a honvédelemről szóló 1993. évi CX. törvény (a továbbiakban: Hvt. 1993). Ez egészen 2005-ig funkcionált, amikor a honvédelemről és a Magyar Honvédségről szóló 2004. évi CV. törvény (a továbbiakban: Hvt. 2004) lépett a helyére. A Hvt. 2004-et a tárgyidőszakban végig alkalmazták, és csak az Alaptörvény hatálybalépésével egyidejűleg helyezték hatályon kívül. ${ }^{183}$

A Hvt. 1976 rendszerváltáson átívelő hatálya valószínúleg elősegítette struktúrájának és rendelkezéseinek továbbélését. A kivételes hatalommal kapcsolatos szabályok jelentős része a korszak mindkét honvédelmi törvényében erős átfedést mutat a Hvt. 1976 szövegével. A Hvt. 1976 megalkotását követően kialakult duális szabályozási koncepció ugyancsak megszilárdult. Amíg azonban az alapvetô szabályokat a korszakban mindvégig az MKA tartalmazta, a Hvt. 1993, majd a Hvt. 2004 egyre terjengősebbé váló fejezetei lassanként elvesztek a részletekben. ${ }^{184} \mathrm{~A}$ honvédelmi törvény túlterheltté válása - ahogy az a Hvt. 1976 esetében is történt - a szabályozás egy részét rendeleti szintre tolta tovább. ${ }^{185} \mathrm{Az}$ így létrejövő „többszintû́ normaszerkezetek" végül a szabályozás alá vont jogintézmény eredeti céljának megvalósulását is veszélyeztették.

A kivételes hatalom lényege ugyanis - mint azt a Kit. 1912-es elfogadásakor az előterjesztő ki is emelte - birtokosának kivételes helyzetben kivételes intézkedésekre való feljogosítása. A Hvt. 1976-tól kezdve törvényenként egyre gyarapodó számú részletszabály viszont nem segítette, hanem akadályozhatta a kivételes hatalom birtokosának eljárását, aki gyors cselekvés helyett könnyen elveszhetett (volna) a formai eloórásokban. ${ }^{186} \mathrm{~A}$ jogalkotó azonban sem 1976-ban, sem később (1993-ban vagy 2004-ben) nem fogadta meg ${ }^{187}$ az 1912-es törvényja-

183 Hatályon kívül helyezte a honvédelemről és a Magyar Honvédségről, valamint a különleges jogrendben bevezethető intézkedésekről szóló 2011. évi CXIII. törvény (a továbbiakban Hvt. 2011), amely már az Alaptörvény felhatalmazása alapján került megalkotásra.

184 Itt fontos megemlíteni, hogy az 1990-es évek végén az alkotmánytervezet előkészítéséhez kapcsolódóan történt kísérlet a minősített időszakok rendszerének alkotmányos újragondolására (Somogyvári, 1998, 11081111. o.). Az Alaptörvény tervezetének előkészítésével kapcsolatban a különleges jogrendi esetkörök számának csökkentésére lásd az új Alkotmány elfogadásának előkészítéséről szóló 9/2011. (III. 9.) OGY határozatot, illetve ennek elemzésére: Till, 2017a, 46-47.

185 Vö.: Hvt. 1976 és a végrehajtására kiadott 6/1976. (III. 31.) MT rendelet; Hvt. 1993 és a végrehajtására kiadott 178/1993. (XII. 27.) Kormányrendelet; Hvt. 2004 és a végrehajtására kiadott 71/2006. (IV. 03.) Kormányrendelet.

186 Ami a szocializmus időszakában, az ország látszólagos szuverenitása mellett amúgy csak formaságnak számított, az az 1989 után visszanyert önrendelkezési jog birtokában komoly hatásköri összeütközések okozója lehetett volna.

187 A jogalkotó döntését természetesen számos körülmény befolyásolhatta. Jelen fejezetben terjedelmi okok miatt nem lehetséges a témához kapcsolódó legfontosabb alkotmánybírósági határozatok elemzése, amelyek a jogalkotó döntési helyzetének határait nagymértékben befolyásolták [lásd különösen a 2/1998. (II. 4.) AB határozatot, az 50/2001. (XI. 29.) AB határozatot, valamint a 102/E/1998. AB határozatot]. 
vaslat kodifikátorainak intelmét, akik a kivételes hatalom minél absztraktabb és egyszerúbb szabályozása mellett érveltek. ${ }^{188}$

A korszak két honvédelmi törvényének a kivételes hatalom birtokában meghozható intézkedésekről, valamint a kivételes hatalom gyakorlására feljogosítottak köréről szóló részeit az alábbiakban tekinthetjük át.

\subsubsection{A rendkivüli intézkedések szabályozása (különleges jogrend)}

A szocializmus korának honvédelmi törvényei a Hvt. 1939 által átmeneti intézkedéseknek $^{189}$ nevezett jogalkotási felhatalmazásokat rendkívüli intézkedések elnevezés alatt tartalmazták. Ez a fogalom, amely 2011 óta a különleges jogrend idején foganatosítható intézkedéseket jelöli a joganyagban, a rendszerváltást követően továbbélt; a Hvt. 1993 és a Hvt. 2004 egyaránt ezt használta.

Láthattuk, hogy a Hvt. 1939 kivételeshatalom-fogalmához tartozó intézkedések egy része a Hvt. 1976-ban már a Rendkivuüli intézkedések fejezeten kívül került elhelyezésre. Ezek a szabályok a rendszerváltást követően sem tértek vissza a Kivételes hatalom fejezetbe, hanem kötelezettségekként előbb a rendkívüli intézkedésekhez kapcsolódva (Hvt. 1993 VIII. fejezet), majd attól rendszertanilag is távol kerülve (Hvt. 2004 II. fejezet) kerültek kodifikálásra.

A rendkívüli intézkedések (Hvt. 1993 IX. fejezet, Hvt. 2004 XIV. fejezet) tagolása csak kismértékben változott a tárgyidőszakban. Az általános rendelkezések mellett a rendkívüli intézkedések négy csoportját ${ }^{190}$ különítette el a jogalkotó: a honvédelmi igazgatásra vonatkozó intézkedések; a közigazgatásra, közrendre, közbiztonságra vonatkozó intézkedések; az igazságszolgáltatásra vonatkozó intézkedések; a gazdasági és anyagi szolgáltatási kötelezettségre vonatkozó intézkedések. A Hvt. 2004-ben ehhez egy külön cím, A megelőző védelmi helyzettel kapcsolatos szabályok és intézkedések kapcsolódtak.

A korszak honvédelmi törvényei a honvédelmi igazgatásra vonatkozó intézkedések cím alatt a rendkívüli szolgálat szabályait helyezték el. ${ }^{191} \mathrm{Az}$ igazságszolgáltatásra vonatkozó in-

188 „A törvényjavaslat [...] felhatalmazza a minisztériumot [értsd: a kormányt - D. E.] arra, hogy a [...] kivételes hatalmat a szükség mértékéhez képest igénybe vehesse, vagyis hogy bizonyos kivételes intézkedéseket a következő szakaszokban felállított korlátok közt a szükség mértékéhez képest megtehessen. Lehetetlen ugyanis pontosan előre látni, hogy az egyes adott esetekben mily kivételes intézkedések megtétele lesz szükséges. Ez okból bízza a törvényjavaslat ennek megítélését és megállapítását a további szakaszok által vont korlátok közt a kormányra, de e széles körủ felhatalmazás korlátozásául szolgál a törvényszakasznak az a rendelkezése is, hogy a kormány a kivételes hatalmat csakis a szükség mértékéhez képest veheti igénybe, tehát a törvényjavaslat következő szakaszaiban részletezett kivételes hatalomból mindenkor csakis annyit alkalmazhat, a mennyit az adott esetben a fennforgó viszonyok és körülmények okvetlenül szükségessé tesznek." Indokolás az 1912. évi LXIII. törvénycikk tervezetéhez (részletes indokolás az 1. \$-hoz).

189 Hvt. 1939141. \$ (9) bekezdés.

190 A Hvt. 1976-ban még csak két csoport szerepelt a rendkívüli intézkedések cím alatt:állam- és közbiztonsággal kapcsolatos intézkedések; gazdálkodást érintő és egyéb intézkedések (Hvt. 1976 55-56. \$).

191 Vö.: Hvt. 1993 202-206. \$ és a Hvt. 2004153-158. \$. 
tézkedések körében vegyes, az igazságszolgáltatás szervezetét, ${ }^{192}$ illetve múködését ${ }^{193}$ érintő szabályok kerültek kodifikálásra. ${ }^{194}$ A rendkívüli intézkedések ezen csoportja egyébként a Hvt. 1976 egy rövid, a statáriális bíráskodás elrendelését lehetôvé tevő bekezdéséből vált önálló címmé a Hvt. 1993-ban. ${ }^{195}$

A két, már a Hvt. 1976-ban is létező cím közül a közigazgatásra, közrendre, közbiztonságra vonatkozó intézkedések a rendkívüli intézkedések legrégebbi, már az 1912-ben elfogadott Kit. óta folyamatosan bővülő csoportját ölelték fel. Hagyományosan itt kerültek elhelyezésre az egyesülési, a gyülekezési joggal, az utazással (ki- és beutazási tilalom) és a mozgásszabadsággal (például kijárási tilalom) kapcsolatos korlátozások, a sajtóellenőrzés (cenzúra) szabályai. A Hvt. 1993 ehhez - a hatalommegosztás elvét érvényesítve - eljárásra jogosult vagy kötelezett személyeket, valamint feladat- és hatásköröket rendelt hozzá, amiket a Hvt. 2004 is átvett, illetve pontosított. ${ }^{196}$

A Hvt. 1976-ban kodifikált gazdasági rendkívüli intézkedések több okból sem illeszkedtek hézagmentesen a törvény szövegébe. Egyrészt a fogalmak meghatározása nem volt egyértelmú, másrészt a Hvt. 1939, amelynek mintájára a cím készült, egy tôkés gazdasági rendszerben fogant, amelynek gazdálkodási részre vonatkozó intézkedései csak nehezen voltak beleilleszthetők a szocialista jogrendbe. A rendszerváltást követő gazdasági változások kedvezően hatottak e cím újraszabályozására. A Hvt. 1993 által kidolgozott anyagi szolgáltatási kötelezettségre vonatkozó intézkedések körében egyrészt kötelezettségek, ${ }^{197}$ másrészt korlátozó rendelkezések, ${ }^{198}$ harmadrészt rendkívüli eltérést lehetôvé tévő szabályok kerültek elhelyezésre. ${ }^{199} \mathrm{Ez}$ a cím is tartalmazott eljárási szabályokat, feladat- és hatásköri elő́rásokat. A Hvt. 1993 rendelkezéseinek többségét a Hvt. 2004 is átvette. ${ }^{200}$

\subsubsection{A kivételes hatalom gyakorlója}

A Hvt. 1976 fontos újítása volt, hogy a HT szabályozásával megteremtette az alkotmányi és törvényi rendelkezések összhangját. A HT-re vonatkozó szabályozás azonban minimális és - láthattuk - a magyar jogi hagyományoktól eltérő volt. A rendszerváltást követően az MKA - a hatalommegosztás elvének megfelelően - a kivételes hatalom gyakorlására több

192 Például bíróságok és ügyészségek létesítése, bírói és ügyészségi önkormányzati szervek múködésének felfüggesztése, bírák ideiglenes kirendelése.

193 Például a rögtönbíráskodás szabályainak alkalmazása, eljárások felfüggesztése, a holtnak nyilvánítás szabályainak módosítása.

194 Vö.: Hvt. 1993224-232. \$ és a Hvt. 2004176-184. \$.

195 Lásd: Hvt. 1976 55. \$ (8) bekezdés.

196 Vö.: Hvt. $1993207-223$. \$ és a Hvt. 2004159-175. \$.

197 Például szerződéskötési kötelezettség, devizaérték vagy nemesfém kötelező vételre felajánlása.

198 Például kötött munkaerő-gazdálkodás, közlekedési infrastruktúra használatának korlátozása, jegy- vagy utalványrendszer bevezetése.

199 Például adók és illetékek mértékének módosítása, fejezeti előirányzatok módosítása.

200 Vö.: Hvt. 1993 223-248. \$ és a Hvt. 2004185-200. \$. 
szervet, illetve személyt is feljogosított. A kivételes hatalom gyakorlására jogosult a tárgyidőszakban az adott kivételes helyzettől függően a Honvédelmi Tanács, a köztársasági elnök vagy a kormány lehetett. Az országgyưlés ellenőrzési jogának alapvető szabályait szintén az MKA rögzítette.

A Hvt. 1993 egyik jelentős érdeme a korábban hiányzó, HT-re vonatkozó részletes szabályozás megalkotása és rendszerbe foglalása volt, amely egyébként a legtöbb esetben az egyes hatáskörgyakorlók együttmúködésére épülő alkotmányi koncepció más szereplőire vonatkozóan is tartalmazott kiegészítő szabályokat. ${ }^{201} \mathrm{~A}$ kivételes hatalom gyakorlójára vonatkozó rendelkezéseket - szerkezetileg részben más helyre iktatva - a Hvt. 2004 is megőrizte. ${ }^{202}$

A Hvt. 1993 HT-ről szóló fejezete két címre tagolódik: a) hatásköri szabályok ${ }^{203}$ és b) a HT múködése. ${ }^{204} \mathrm{Az}$ elsô cím alatt a feladat- és hatáskörök mellett a mentelmi jog, a HT megalakításához és mûködéséhez szükséges helyettesítési sorrendek találhatók. A második cím az ügyrend megalkotásával, a döntéshozatallal, az érvényességi kellékekkel és a döntések közlésével kapcsolatos szabályokat tartalmazza. Egyes értelmező rendelkezéseket külön cím alatt (Általános rendelkezések), a rendkívüli intézkedésekról szóló fejezetben helyezte el a jogalkotó. ${ }^{205}$

\subsection{A kivételes hatalom kodifikálásának tanulságai az 1989-2011 közötti időszakban}

A kivételes hatalommal kapcsolatos joganyag rögtön az 1989-es alkotmányrevízióval minőségi változáson ment keresztül, a korábban a Hvt. 1976-ban található, de egységes koncepcióba nem foglalt esetköröket alkotmányi szinten rögzítették. Az esetkörök az elkövetkező másfél évtizedben gyarapodásnak indultak, számuk háromról ötre növekedett. A kivételes hatalom gyakorlására jogosultak körét - ugyancsak 1989-ben - alkotmányi szinten újra meghatározták. Ennek részeként a HT egyértelmú szabályozást nyert.

A részletszabályokat a korszak legjelentősebb ágazati törvénye, a Hvt. 1993 tartalmazta, amely azonban szerkezetében jelentős mértékben támaszkodott elődje, a Hvt. 1976 megoldásaira. A Hvt. 1993 kivételes hatalomra vonatkozó szabályozása talán éppen ezért sikeredett felemásra. Egyes részek, mint a HT hatásköreire és működésére vonatkozó rendelkezések előremutatók, mások, mint például a különleges jogrendre vonatkozó szabályok már-már a jogszabály használhatóságát veszélyeztető mértékben terjengősek. ${ }^{206}$ A Hvt. 1993 téma szempontjából kiemelt rendelkezéseit a Hvt. 2004 szinte változtatás nélkül vette át, sôt még

201 Lásd például a Hvt. 1993 X. fejezet általános rendelkezések címét.

202 Vö.: Hvt. 1993 X. fejezet és a Hvt. 2004 V. fejezet.

203 Hvt. 1993249-251. \$.

204 Hvt. 1993252-256. \$.

205 Hvt. 1993199-201. \$.

206 Itt érdemes megemlíteni, hogy például 1997-ben azért nem született minősített időszaki törvény, mert a 200 szakasz terjedelmú tervezetet az akkori igazságügyi tárca nem találta elég részletesnek. (Köszönet Till Szabolcs lektornak a kiegészítésért!). 
a Hvt. 2011 is erôteljesen támaszkodott arra a struktúrára, amely a 2010-es évekből visszatekintve nemzeti szabályozásnak tûnt, de valójában a Hvt. 1976 egyre halványabban kirajzolódó kontúrját képezte le.

Mindezeket figyelembe véve a kivételes hatalom 1989 utáni kodifikációjának mérlege felemásra sikeredett: jelentős eredmények ${ }^{207}$ mellett a kivételes hatalom jogintézményét nem sikerült megtisztítani a túlterjeszkedő, az esetleges használatot akadályozó szabályoktól. ${ }^{208}$ Ha a jogintézmény egy teljes évszázadot (1912-2011) átívelő kodifikációs kísérletein végigtekintünk, akkor a Hvt. 2011 egy hosszú idő után jó irányba tett lépésnek túnik. ${ }^{209}$

\section{5. Összegzés}

\subsection{Az „alkotmányszegény” ország}

A kivételes hatalommal kapcsolatos korai szabályozás részben alkotmányokhoz kötődött. A több tekintetben példaértékûvé váló francia szabályozás például számos francia alkotmányban is megjelent. Magyarország alkotmánytörténetének egyik jellegzetessége, hogy különböző alkotmánytervezetek ${ }^{210}$ kidolgozása ellenére tartós írott alkotmányt csak a 20. század közepére sikerült létrehozni (2.2. pont). ${ }^{211}$

A kivételes hatalommal kapcsolatos szabályozás így kezdetben a történeti alkotmányban foglalt szabályozás részeként jelent meg, ${ }^{212}$ az első kodifikációs kísérlete, valamint a gyakorlati alkalmazás is katonai érdekek mentén valósult meg a 19. század közepén. Az első részletes szabályozásra viszonylag későn, ${ }^{213}$ ugyancsak katonai érdekből és törvénnyel került sor.

A jogintézmény már túljutott kodifikációs „csúcspontján” (Hvt. 1939), mire 1972-ben egyértelmú szabályozást kapott az alkotmányban. Innentől kezdve beszélhetünk a kivételes hatalom tekintetében valódi duális szabályozásról, amelynek egyes elemei azonban csak aZ 1989-es alkotmányrevíziót követően foglalták el végleges helyüket.

207 Például az 1989-ben kidolgozott alkotmányi szabályozás vagy a Hvt. 1993 HT-re vonatkozó rendelkezései.

208 E tekintetben csak a Hvt. 2011 hozott minőségi javulást, amikor a jogalkotó a már létező joganyagot teljes egészében felülvizsgálta, és nem riadt vissza a fogalmak évtizedek óta elmaradt tisztázásától sem (lásd például: a különleges jogrend megjelenése a Hvt. 2011 címében). A fogalomhasználat eltéréseinél elegendô csak utalni arra, hogy az alkotmány módosításáról szóló 1989. évi XXXI. tv. javaslatához készült indokolás a „különleges hatalom" (Részletes indokolás az 5. \$-hoz), a módosított alkotmányi rendelkezéseket elemző tudományos írás a „rendkívüli hatalom" (Újfalvi, 1990) kifejezést használta, miközben a Kit. [1. \$ (1) bekezdés] és a Hvt. 1939 [141. \$ (1) bekezdés] egyértelműen kivételes hatalomról beszélt.

209 Újabb előremutató jogfejlesztés csak a járvány időszakában szerzett gyakorlati tapasztalatok nyomán várható. Vö.: az Alaptörvény kilencedik módosításának vonatkozó részeit (T13647. számú törvényjavaslat, 2020. 11. 30., illetve annak egységes szerkezetbe foglalt, 13647/15. számú változatát, 2020. 12. 14.).

210 Átfogóan lásd: Horváth, 2012.

211 Lásd még: Domaniczky, 2009.

212 Vö.: Virozsil, 1861, 132-133. o.

213 Ehhez képest lásd a nemzetközi példákat az 1.1.2. pontban. 


\subsection{A kivételes hatalom jogszabálybokrai és többszintü normaszerkezetei}

Az 1912-ben garanciákkal szilárdan körülbástyázott Kit. az I. világháború alatt gyorsan általános kodifikációs hivatkozási alappá vált. Az összeomlást követően pedig kiderült, hogy felhatalmazása, illetve az ennek alapján már létrejött „jogszabálybokrok” alkalmazása nélkülözhetetlen az államszervezet és a nemzetgazdaság újjászervezéséhez, erre tekintettel hatályát folyamatosan meghosszabbították. Rövidesen azonban az is nyilvánvalóvá vált, hogy a Kit. felhatalmazása alapján kibocsátott rendelettömeg önálló életre kelt, szinte minden passzusából különböző, többször módosított rendeletbokrok nőttek ki. Ezek deregulációjával az 1920-as és az 1930-as években is megpróbálkoztak, de még a Rákosi-rendszerben is előfordult, hogy egyes, a Kit.-re tekintettel kibocsátott jogszabályokat külön hatályon kívül kellett helyezni. ${ }^{214}$

Az 1930-as években a Kit. utódjául szolgáló Hvt. 1939-ben a jogszabályi hierarchia biztosítása érdekében már külön beépítettek az átmeneti időszakra, illetve a kivételes hatalom alapján kibocsátott joganyag további sorsára vonatkozó szabályokat. ${ }^{215}$

A Hvt. 1939 alapján a II. világháború időszakában szintén jelentős mennyiségú joganyag keletkezett, ám ezek hatályon kívül helyezését a jogalkotó helyett végül a történelmi helyzet oldotta meg. Az 1945-ben megalakult Nemzetgyúlés viszonylag korán szabályozás alá vonta a kivételes hatalom intézményét, ${ }^{216}$ ám a Kht.-t eredetileg is csak átmeneti jellegú jogszabálynak szánhatták.

A korlátozott szuverenitással rendelkező országban a kivételes hatalom elvesztette a korábbi jelentôségét, hiszen az állammal összenôtt párt enélkül is szabad kezet kapott elképzelései megvalósításához. Az 1949-1989 közötti időszak honvédelmi törvényei azonban - nyilvánvalóan a Hvt. 1939 koncepciójának hatása alatt - kétszer is újrakodifikálták a jogintézményt. A korábbi feszes, célhoz kötött szabályozás azonban egyre terjengősebbé, esetenként többszintűvé vált („többszintû normaszerkezetek”), ami - ha szükség lett volna rá a kivételes hatalom felhasználását jelentős mértékben megnehezíthette volna.

\subsection{Kivételesből általános jellegü keretszabályozás}

A Kit. megalkotásakor a kormány és a jogalkotók nagy része is egy adott háborús helyzet kezelésére készült, amelynek végeztével a kivételes hatalom időszaka is véget ér. Sajnos már a háború első hónapjaiban rá kellett döbbenniük, hogy a kivételes hatalomra és az általa biztosított eszközrendszerre - a közösség érdekében - hosszabb ideig is szükségük lehet; ez a felismerés jelenik meg a törvény 1914-es módosításában. ${ }^{217}$

214 Vö. például: az egyesülési jogról szóló 1955. évi 18. tvr. 16. \$.

215 Lásd: Hvt. 1939141. \$(9) bekezdés.

216 1946. évi VI. törvény.

217 A háború esetére szóló kivételes intézkedésekről alkotott 1912:LXIII. törvénycikknek és a hadiszolgáltatásokról szóló 1912:LXVIII. törvénycikknek kiegészítéséről szóló 1914. évi L. törvénycikk. 
A háború végén pedig a teljes szuverenitását visszanyert ország döntéshozói újabb és újabb - elôre nem látott - rendkívüli helyzetekkel találkoztak: háborús megszállás, államterület és -határok rapid változása, polgárháború, gazdasági válság. Ezek kezelése évekig eltartott, és mindegyikük a korábban látott és megszokott módszerektől eltérô megközelítést, gyors reagálást és újfajta eszközrendszert igényelt. A kivételes hatalomról szóló törvény és az azon alapuló alacsonyabb szintú jogszabályok egy része önmagától is elvesztette aktualitását, ${ }^{218}$ más részük azonban a világháború után is hatályban maradt, hosszabb távon is állandósítva a kivételes helyzetet.

A két világháború korának (1918-1939) időszakában a kivételes hatalom jelentőségét a kivételes helyzet állandósulása adta, ami lehetôvé tette az eredetileg háborúra tervezett rezsim békeidejú felhasználását. Addig, amíg a jogalkotó is felismerte, hogy a háborús szabályozás békeidejû́ alkalmazásában számos, korábban kihasználatlan lehetôség rejlik, még évtizedek teltek el. A kivételes helyzetek három esetkörének Hvt. 1976-ban történt kodifikálása viszont egy újabb, a kivételes hatalom háborús és békeidejư felhasználásának egyaránt új irányokat szabó időszak (1976-2011) nyitányát jelentette. Az ez irányú jogfejlesztés az Alaptörvény, illetve a Hvt. 2011-es elfogadásában csúcsosodott ki.

\subsection{Politikai rendszereken átívelő szabályozási tárgy}

A kivételes hatalom és a Kit. felhatalmazása alapján létrejött különleges jogrend - láthattuk - még a folyamatos rendszerváltásoktól terhelt 20. századi magyar történelemben is állandónak bizonyult. A jogintézmény megjelenési formája, a jogforrás időről időre változott, de 1912 és 1949 között szinte folyamatosan használták, és - mint a kormányzás nélkülözhetetlen eszközét - rendszereken átívelően fejlesztették.

Az 1912-es alapjogszabály hatályát 1914 és 1918 között többször is kiterjesztették. A Károlyi-kormány kivonta a hatálya alól az alapjogok egy részét, amely - ha a korlátozásukat lex specialisként külön rendezik, mint az például az 1867-es osztrák törvényben történt - akár egy új jogfejlesztési iránnyá is válhatott volna, ha néhány hónapon belül zárójelbe nem teszik.

Az 1920-as években a háború alatt megszilárdult jogkört gyakorolták, a Hvt.-ben pedig a két évtizedes gyakorlatot rendszerbe foglalva újraszabályozták. Az 1940-es évek második felében - elsősorban az 1930-as években bevezetett gazdasági jellegú kivételes hatalom mintájára - egy ideiglenes szabályozást fejlesztettek ki, majd kodifikáltak.

218 Ahogy az 1920. évi VI. törvény javaslatának indokolása megfogalmazta: „Ezek az intézkedések nagyrészben olyan természetúek ugyan, hogy a háború megszúntével céljukat vesztették és vagy máris hatálytalanoknak tekinthetők, vagy nehézség nélkül hatályon kívül helyezhetők; mindazáltal nagy számmal vannak közöttük olyanok is, amelyek a háború által teremtett rendkívüli helyzet kényszerítő hatása alatt olyan viszonyokat szabályoztak, amelyek a háború következtében újonnan keletkeztek vagy a lényegesen átalakult körülmények miatt új szabályozást kívántak, s amelyekre nézve a kivételes hatalom alapján alkotott szabályoknak egyszerú és rögtönös megszüntetése zavarok és bonyodalmak felidézése nélkül egyáltalában nem lehetséges." Vö.: 1920. évi VI. törvény 1. \$ (3) bekezdés. 
Az 1949-es alkotmány ezt a kérdést megkerülte, ${ }^{219}$ helyette a kivételes hatalom az 1960-as honvédelmi törvényben kapott helyet, ahol - bár az 1939-es Hvt. rendszerét tükrözi - a szabályozás jelentős mértékủ visszalépéssel járt a korábbi Hvt. koncepciójához képest. Ez a negatív irányú jogfejlődés elsősorban a kivételes hatalom elértéktelenedésére utalhat. A pártállam látszólagos jogrendjében ugyanis a kérdés elvesztette jelentőségét. Nem kellett szabályozni, mert a hatalommegosztás csak papíron létezett, és a gyakorlását sem kellett korlátozni, mert a párt minden szervben és intézményben korlátlan hatalommal rendelkezett. ${ }^{220}$

Az 1989-es rendszerváltás egy újabb dinamikus kodifikációs szakasz nyitányának tekinthető. A téma alkotmányi és törvényi szinten is új szabályozást nyert, egyrészt a némileg túlszabályozott szocialista joganyagra építkezve (rendkívüli intézkedések köre), másrészt viszont annak külföldi minták segítségével történő továbbgondolása révén (a kivételes helyzetek esetkörei, a kivételes hatalom gyakorlására jogosítottak személyi köre). Ami a korszakban (1989-2011) fájó hiányosság maradt, az a magyar jogi hagyományoknak a legújabb külföldi jogfejlődés eredményeivel való összevetése és ötvözése. Erre csak a tárgyidőszak végén, 2011-ben történt kísérlet.

\subsection{Dinamikus és statikus periódusok a kivételes hatalom kodifikációja során}

A kivételes hatalom szabályozásának történetét kísértük figyelemmel a kezdetektől egészen 2011-ig. Látható volt, hogy Magyarországon - bár több nemzetközi (köztük 1867-től az osztrák) példa is rendelkezésre állt - a szabályozás késôn és honvédelmi kérdésként jelentkezett. A kérdéshez a tárgyalt időszakban mindvégig az államérdek oldaláról közelítettek, az emberi jogokkal való összekapcsolódás - mint például 1867-ben Ausztriában - itthon (egy rövid kivételtől eltekintve) nem történt meg (erre majd csak 1989 után ${ }^{221}$ került sor).

Bár a kivételes hatalom szabályozási koncepciója 1912 és 1939 között folyamatosan változott, és közben egyre részletesebbé vált, a kivételes hatalom polgári irányítás (kormány) alá rendelésének elve állandósult. A törvény megalkotásának célja kezdetben az állam múködtetésének megkönnyítése volt, ám a II. világháború alatt fokozatosan az államszervezet totális irányítását lehetővé tevő eszközzé vált. A kivételes hatalom 1946-1949 közötti ideiglenes szabályozása ugyancsak az államhatalom megszerzésének eszközéül szolgált.

Ezt követően a jogintézmény egészen 1989-ig nem állt a figyelem középpontjában. Szabályozását - elsősorban a korábbi szabályozás mintájára - fontosnak tartották, de a jogfejlesztés több részletben, egységes koncepciót nélkülözve zajlott. Erre tekintettel, összevetve

219 Pontosabban a Kht. szabályozása az Elnöki Tanács hatásköreinek megvonásánál szolgálhatott mintaként. Vö.: 1949. évi XX. tv. 20. \$ (4)-(5) bekezdés.

220 Bővebben lásd: Bihari, 2005.

221 Egyrészt az MKA módosítása révén, amelynek XII. fejezete részletesen felsorolta az alapvető jogokat és kötelességeket, miközben előírta, hogy az alkotmány alkalmazása rendkívüli állapot idején sem függeszthető fel. Másrészt Magyarország 1993-ban jogrendje részévé tette az Emberi Jogok Európai Egyezményét (1993. évi XXXI. tv.), amelynek 15. szakasza szükséghelyzet idején lehetôvé teszi egyes emberi jogok korlátozását. 
az 1912-1949 közötti dinamikus szakasszal, 1949-1989 között egy alapvetően statikus kodifikációs időszakról beszélhetünk. A kivételes hatalom szabályozása 1989-ben került újra előtérbe, de a periódus (1989-2011) egészét - néhány év (1989-1993) kivételével - inkább az átmeneti, mint dinamikus jelzővel lehetne jellemezni.

\subsection{Az egyévszázados kodifikáció mérlege}

A kivételes hatalom modern szabályozása egy nehézkesen induló kodifikáció során került a magyar joganyagba. A jogalkotó a korban már létező generális szabályozás (például a korabeli osztrák törvény) átvétele helyett kifejezetten a háborús helyzet kezelését kívánta megkönnyíteni egy saját fejlesztésû́ törvénnyel. A szabályozást később analógiával a válságokkal terhelt békeidőre is alkalmazhatóvá tették, de a konkrét békeidejû rendelkezések kidolgozása egészen 1976-ig elmaradt.

A kivételes hatalom szabályozása az elmúlt évszázad nagyobbik részében döntően monista volt. Az alkotmányi és törvényi szint duális szerkezethez szükséges összhangját csak 1972-ben tudta megteremteni a jogalkotó. Azóta a szabályozás többnyire mindkét szinten egy időben vagy közel egy időben valósul meg. A joganyag két szint közötti eloszlását a korszakban legutóbb 2011-ben, előtte 1989-ben vizsgálták felül.

A jogintézményt érintő rendelkezések száma a tárgyidőszakban fokozatosan növekedett. A Hvt. 1939 különböző jogtechnikai megoldásokkal próbálta a szabályok és a szabályozók számát csökkenteni. Ennek részeként magát a jogintézményt is újrakodifikálta. Ilyen jellegû, tudatos, egységes koncepció mentén zajló kodifikáció a kivételes hatalommal kapcsolatos szabályokat legközelebb csak 1989-ben érintette. Kodifikáció természetesen a tárgyidőszak többi (1939-1989 és 1989-2011) részében is történt, de e változások többsége elsősorban kismértékủ és deskriptív jellegú volt.

Láthattuk, a szabályozási tárgy politikai rendszerváltozásoktól függetlenül mindvégig létezett, e 20. századi magyar történelemre oly jellemző rendszerváltozások egyik legfontosabb hatása talán a kivételes hatalomra vonatkozó koncepcionális jogfejlesztés elmaradásában jelölhető meg. Az újabb tervezetek elsősorban az akkor hatályos szabályozásra támaszkodtak, és - talán ideológiai okokból is - mind az 1912-es, mind az 1939-es törvény szerkezetének, jelentőségének felmérése és értékelése hosszú ideig váratott magára, és csak az I. világháború centenáriumához kapcsolódva kezdődött meg a jogintézmény korai történetének vizsgálata.

E tudományos igényú, jogtörténeti jellegú vizsgálat jelen esetben elsősorban nem az elmélet, hanem a gyakorlat számára járna haszonnal. Az 1989-2011 közötti jogfejlesztés ugyanis - láthattuk - nagymértékben épített a szocialista időszak joganyagára, illetve annak egy részére, ahelyett, hogy a jogintézmény hazai szabályozásának jellegzetességeire, a korábbi koncepciók hol ciklikus, hol hektikus változásaira koncentrált volna. Márpedig a magyar szabályozási előzmények ismerete nélkül az esetek nagy részében a külföldi minták adaptá- 
ciója sem lehet sikeres. Azonban esetünkben ez utóbbi - a külföldi minták - feldolgozása és bemutatása is későn indult meg.

A jogalkotónak a kivételes hatalom újraszabályozására vonatkozó igénye fentiek miatt 2010-ben egyrészt időszerû, másrészt viszont - az összehasonlító jogi vizsgálatok elmaradása miatt - talán idő előtti volt. A következő évtizedben előbb a téma elméleti, ${ }^{222}$ majd 2020-ban gyakorlati oldalának előtérbe kerülése talán egy újabb, átfogó kodifikáció nyitányának tekinthető, amely során az elméleti eredmények, a külföldi minták és a saját gyakorlati tapasztalatok előnyösen ötvözhetôk.

\section{Irodalomjegyzék}

Alkotmányos elvek és esetek (1996). 1. kiadás. Budapest: Colpi

ÁDÁm, A. (1967a) 'Az Elnöki Tanács hatáskörének fejlődése I.', Állam és Igazgatás, 17(4), 310322. 0.

ÁDÁm, A. (1967b) 'Az Elnöki Tanács hatáskörének fejlődése II.', Állam és Igazgatás, 17(5), 424435. 0.

BIHARI, M. (2005) Magyar politika 1944-2004. Politikaiés hatalmi viszonyok. 1. kiadás. Budapest: Osiris.

BIHARI, O. (1979) 'Alkotmányok és alkotmányozás a Magyar Tanácsköztársaságban', Állam és Igazgatás, 29(3), 193-202. o.

BuzA, L. (1915) 'Az államjogi kivételes állapot', Jogtudományi Közlöny, 50(27), 305-306. o.; (28), 313-314. o.; (32), 350-351. o.; (33), 361-362. o.; (36), 386-387. o.

Concha, Gy. (1888) Újkorialkotmányok. 1. kiadás. Budapest: MTA

CzANK, L. (1978) 'A honvédelmi munkakötelezettségről az új honvédelmi törvény tükrében', Honvédelem, 19(8), 94-104. o.

DEÁk, Á. (2001) 'Az 1867. decemberi ausztriai törvénycikkek a közös ügyekról és azok kezelési módjáról', Aetas, 16(3), 238-243. o.

DEÁK, I. (1983) Kossuth Lajos és a magyarok 1848-49-ben. 1. kiadás. Budapest: Gondolat

DomANiczKy, E. (2009) A jogállam és a civil szektor Magyarországon, különös tekintettel a helyi önkormányzatokra. 1. kiadás. Budapest: Publikon

DomanıczKY, E. (2010) 'Az első magyar egyesülési törvényjavaslat', Közjogi Szemle, 3(2), 26-34. o.

222 Elméleti és gyakorlati szempontból is kifejezetten előremutató volt a Pázmány Péter Katolikus Egyetem, az MTA TK JTI és a Magyar Katonai Jogi és Hadijogi Társaság által 2017-ben közösen szervezett, $A$ különleges jogrend címú konferencia, ahol az elhangzott előadások összegezték az addigi „nemzetközi jogi, hazai és külföldi alkotmányjogi, közigazgatási jogi, büntetőjogi, jogelméleti és jogtörténeti, valamint politikatudományi kutatásokat" (Jakab, 2017, 1. o.; Till, 2017b; Tóth, J., 2017). Lásd még továbbá: Lakatos, 2014; Till, 2014; Kádár, 2014. 
Domaniczky, E. (2012) 'Adalékok a magyar egyesülési jog szabályozásához a dualizmus korában', Jogtörténeti Szemle, 14(1), 1-17. o.

EÖTtevÉNyi Nagy, O. (é. n.) Ausztria nemzetiségi politikája [Online]. Elérhetô: http://mtda.hu/ ADATTAR/cikktar/e_cikk/eottevenyi_nagy_oliver_ausztria_nemzetisegi_politikaja.pdf (Letöltve: 2020. június 7.)

FARKAS, Á., KÁDÁR, P. (szerk.) (2016) Magyarország katonai védelmének közjogi alapjai. 1. kiadás. Budapest: HM Zrínyi Térképészeti és Kommunikációs Szolgáltató Közhasznú Nonprofit $\mathrm{Kft}$.

Feitl, I. (szerk.) (1995) Az Ideiglenes Nemzetgyúlés és az Ideiglenes Nemzeti Kormány 1944-1945. 1. kiadás. Budapest: Politikatörténeti Alapítvány.

Felszeghy, B. (1914) 'A belső igazgatást érdeklő kivételes intézkedések', Közigazgatási Szemle, I(I), 473-485. o.

FöGLEIN, G. (1992) 'Az államföi jogkör ideiglenes szabályozása és gyakorlása Magyarországon 1944-1946 között', Jogtörténeti Szemle, 4(5), 3-15. o.

GalántaI, J. (1981) 'A háborús állam. A „kivételes hatalom” kodifikálása és alkalmazása 1914-1916-ban' in Pölöskei, F., Ránki, Gy. (szerk.) A magyarországi polgári államrendszerek. 1. kiadás. Budapest: Tankönyvkiadó

Germuska, P. (2011) A Honvédelmi Tanács és a Honvédelmi Bizottság Magyarországon, 1952-1980 [Online]. Elérhetô: www.nationaler-verteidigungsrat.de/downloads/germuska_ht_hb.pdf (Letöltve: 2020. december 1.)

GyARMATI, Gy. (2011) A Rákosi-korszak. 1. kiadás. Budapest: ÁBTL-Rubicon

HERMANN, R. (1998) 'A kormánybiztosi rendszer 1848-1849-ben', Hadtörténeti Közlemények, 111(1), 28-77. 0.

HermanN, R. (1999) 'A kormánybiztosi rendszer 1848-1849-ben' in Bessenyei, J., Fügedi, M., Ö. Kovács, J., Ringer, Á., Schimert, P. (szerk.) Történelmi tanulmányok. A Miskolci Egyetem történettudományi tanszékeinekévkönyve 1999. 1. kiadás. Miskolc: Miskolci Egyetem BTK

HoRváth, A. (2012) 'Alkotmányjogi javaslatok és reformok, 1790-1949' in Jakab, A., Körösényi, A. (szerk.) Alkotmányozás Magyarországon és máshol: politikatudományi és alkotmányjogi megközelitések. 1. kiadás. Budapest: Új Mandátum Kiadó - MTA TK PTI

JAKAB, A. (2017) 'Előszó', Iustum Aequum Salutare, (13)4, 1. o.

JÁNosi, F. (1867) Alkotmányok gyüjteménye. 1. kiadás. Pest: Pfeifer.

KÁDÁR, P. (2014) 'Sarkalatos átalakulások: A kétharmados/sarkalatos törvények változásai a honvédelem területén 2010-2014', MTA Law Working Papers, 2014/36. [Online]. Elérhetô: https://jog.tk.hu/mtalwp/sarkalatos-atalakulasok-a-ketharmadossarkalatostorvenyek-valtozasai-a-honvedelem-teruleten-2010-2014?download=pdf (Letöltve: 2020 . december 10.)

Katus, L. (2012) A modern Magyarország születése. 1. kiadás. Pécs: PTKE-Kronosz

Kelemen, R. (2016) 'A háború esetére szóló kivételes intézkedéseket tartalmazó 1912. évi LXIII. törvény országgyúlési vitája és sajtóvisszhangja', Parlamenti Szemle, 1(1), 70-91. o. 
Kelemen, R. (szerk.) (2017) Források a kivételes hatalom szabályozásának magyarországi geneziséról. 1. kiadás. Budapest: Magyar Katonai Jogi és Hadijogi Társaság

KELEMEN, R. (2018) 'A Honvédelmi Tanács. Szerves fejlődés vagy elnevezésbeli hasonlóságok a magyar jogtörténetben? (Honvédelmi Bizottmány - Legfelső Honvédelmi Tanács Honvédelmi Tanács szabályozása, jellege)', Katonai és Hadijogi Szemle, 2018/1, 63-94. o.

KIss, I. (1886) Magyar államjog. 1. kiadás. Eger: Lyceum Könyvnyomda

LAKaTos, L. (2014) 'A különleges jogrend és a honvédelem szabályzása' MTA Law Working Papers, 2014/49. [Online]. Elérhető: https://jog.tk.hu/mtalwp/a-kulonleges-jogrend-es-ahonvedelem-szabalyzasa (Letöltve: 2020 . december 8.)

LuKACs, J. (2020) A huszadik század rövid története. 1. kiadás. Budapest: Európa

MEZEy, B. (2016) 'Az első világháború jogi törvényhozói előkészítése: a kivételes hatalomról szóló 1912. évi 63. törvénycikk' in Kónya, P. (szerk.) Elsô világháború a Kárpátokban. 1. kiadás. Eperjes: Eperjesi Egyetem

Mezey, B. (szerk.) (2003) Magyar alkotmánytörténet. 1. kiadás. Budapest: Osiris

Mezey, B. (2015) 'A kivételes hatalom jogi természete', Jogtörténeti Szemle, 17(4), 25-32. o.

Moskovitz, I. (1906) 'A kormánybiztos', Jog, 25(4), 25-27. o.

MURBeR, I. (2018) 'Az osztrák és a magyar válságkezelés 1918-1920. Hasonlóságok és különbségek a közös birodalom összeomlását követően', Századok, 152(6), 1293-1320. o.

PALASIK, M. (2000) A jogállamiság megteremtése és kudarca Magyarországon 1944-1949. 1. kiadás. Budapest: Napvilág

Palasik, M. (2017) Parlamentarizmustól a diktatúráig (1944-1949). 1. kiadás. Budapest: Országház Kiadó

Petrétei, J. (2006) 'A minősített időszakokra vonatkozó alkotmányi (törvényi) szabályozás sajátosságai' in Ádám, A., Cseresnyés, F., Kajtár, I. (szerk.): Tanulmányok az 1956. évi forradalom és szabadságharc 50. évfordulójára. 1. kiadás. Pécs: PTE ÁJK

Polner, Ö. (1914) 'A háború okából tett kivételes intézkedések', Jogállam, 7(7-8), 489-512. o.

POLNER, Ö. (1931) 'Jogfolytonosság és ideiglenes alkotmány', Jogállam, 30(3-4), 144-151. o.

POLNER, Ö. (1916) [Polner Ödön előadása a Magyar Jogászegyletben]. Jogtudományi Közlöny, 51(9), 86-87. O.

POLNER, Ö. (1917) 'A háború esetére szóló kivételes hatalom alkotmányjogi jelentősége', Jogállam, 16(1-2), 25-42. 0.; (3-4), 129-150. o.

SÁGVÁRI, Á. (2017) 'Különleges jogrend a francia jogban', Iustum Aequum Salutare, 13(4), 179188. o.

SCHÖNWALD, P. (1969) A magyarországi 1918-1919-es polgári demokratikus forradalom állam-és jogtörténeti kérdései. 1. kiadás Budapest: Akadémiai Kiadó

SCHWeItzer, G. (2018) „A tisztességes jogtanár”-Molnár Kálmán pályaképe. 1. kiadás. Budapest: MTA TK JTI

SOMOGYVÁRI, I. (szerk.) (1998) Az Országgyülés Alkotmány-elókészítő munkájának dokumentumai 1994-1998. (2. kötet) 1. kiadás. Budapest: Parlamenti Módszertani Iroda 
Sz. Bíró, Z. (2017) Az elmaradt alkotmányozás. 1. kiadás. Budapest: Osiris

SzABó, I. (2017) 'Különleges jogrend a weimari alkotmányban', Iustum Aequum Salutare, 13(4), 127-141. 0.

SzÉKELY, S. (1964) 'A honvédelmi munkakötelezettségról', Honvédelem, (15)10, 46-54. o.

SzINAI, M. (1986) 'A parlamenten kívüli kormányzás Ausztriában és Magyarországon az első világháború után', Századok, 120(4), 802-805. o.

TAKÁcs, Gy. (1973) 'A sajtó és a kivételes hatalom', Jogtudományi Közlöny, 28(7-8), 407-411. o.

TILL, Sz. (2014) 'Tézisek az Alaptörvény és a honvédelem sarkalatos törvényi szintjének összefüggéseiről', MTA Law Working Papers, 2014/42. [Online]. Elérhető: https://jog. tk.hu/mtalwp/tezisek-az-alaptorveny-es-a-honvedelem-sarkalatos-torvenyi-szintjenekosszefuggeseirol?download=pdf (Letöltve: 2020 . december 15.)

Till, Sz. (2017a) A honvédelmi alkotmányosság 30 éve Magyarországon 1988-2017. 1. kiadás. Budapest: Zrínyi Kiadó

TiLL, Sz. (2017b) 'A különleges jogrendi kategóriarendszer egyszerúsítésének jövőbeli esélyei', Iustum Aequum Salutare, (13)4, 55-75. o.

TiLL, Sz. (2019): 'Különleges jogrend' in Jakab, A., Fekete, B. (szerk.) Internetes Jogtudományi Enciklopédia [Online]. Elérhető: http://ijoten.hu/szocikk/kulonleges-jogrend (Letöltve: 2020. november 16.)

То́тн, Á. (1967) 'A kivételes állapot intézményének kialakulása néhány burzsoá állam jogrendszerében', Acta Juridica et Politica, 14(8), 1-19. o.

Tóтн, Á. (1982) 'A statárium és az ostromállapot szabályozása 1848-tól a kiegyezésig', Acta Juridica et Politica, 29(5), 1-37. o.

Tóтн, J. Z. (2017) 'A rögtönbíráskodás története Magyarországon a XIX-XX. században', Iustum Aequum Salutare, (13)4, 143-177. o.

ÚjFALVI, A. (1990) '„Szükség törvényt bont” avagy a rendkívüli jogrend szabályozása a Negyedik Köztársaságban', Magyar Közigazgatás, (40)7, 614-625. o.

VARGYAI, Gy. (1979) 'A kivételes hatalom és az államszervezet militarizálásának néhány kérdése Magyarországon a második világháború előestéjén', Jogtudományi Közlöny, 34(11), 756-764. o.

VIROzsIL, A. (1861) Magyarország nyilván- vagy közjoga mint az alkotmánya eredetétól 1847/8-ig fennállott. Buda: Magyar Kir. Egyetemi Nyomda 